\title{
Plant species diversity for sustainable management of crop pests and diseases in agroecosystems: a review
}

\author{
Alain Ratnadass • Paula Fernandes • Jacques Avelino • \\ Robert Habib
}

Accepted: 11 December 2010 /Published online: 17 May 2011

(C) The Author(s) 2011. This article is published with open access at Springerlink.com

\begin{abstract}
Farmers are facing serious plant protection issues and phytosanitary risks, in particular in the tropics. Such issues are food insecurity, lower income in traditional lowinput agroecosystems, adverse effects of pesticide use on human health and on the environment in intensive systems and export restrictions due to strict regulations on quarantine pests and limits on pesticide residues. To provide more and better food to populations in both the southern and northern hemispheres in a sustainable manner, there is a need for a drastic reduction in pesticide use while keeping crop pest and disease damage under control. This can be achieved by breaking with industrial agriculture and using an agroecological approach, whose main pillar is the conservation or introduction of plant diversity in agroecosystems. Earlier literature suggest that increasing vegetational biodiversity in agroecosystems can reduce the impact of pests and diseases by the following mechanisms: (1) resource dilution and stimulo-deterrent diversion, (2)
\end{abstract}

A. Ratnadass $(\bowtie) \cdot$ P. Fernandes

CIRAD, UPR HortSys,

F-34398 Montpellier, France

e-mail: ratnadass@cirad.fr

J. Avelino

CIRAD, UPR Bioagresseurs: Analyse et maîtrise du risque,

F-34398 Montpellier, France

R. Habib

CIRAD, Département Persyst,

F-34398 Montpellier, France

P. Fernandes

PRAM, BP 214,

F-97285 Le Lamentin Cedex 2, Martinique

J. Avelino

CATIE 7170 ,

Turrialba 30501, Costa Rica disruption of the spatial cycle, (3) disruption of the temporal cycle, (4) allelopathy effects, (5) general and specific soil suppressiveness, (6) crop physiological resistance, (7) conservation of natural enemies and facilitation of their action against aerial pests and (8) direct and indirect architectural/ physical effects. Here we review the reported examples of such effects on a broad range of pathogens and pests, e.g. insects, mites, myriapods, nematodes, parasitic weeds, fungi, bacteria and viruses across different cropping systems. Our review confirms that it is not necessarily true that vegetational diversification reduces the incidence of pests and diseases. The ability of some pests and pathogens to use a wide range of plants as alternative hosts/reservoirs is the main limitation to the suppressive role of this strategy, but all other pathways identified for the control of pests and disease based on plant species diversity (PSD) also have certain limitations. Improving our understanding of the mechanisms involved should enable us to explain how, where and when exceptions to the above principle are likely to occur, with a view to developing sustainable agroecosystems based on enhanced ecological processes of pest and disease control by optimized vegetational diversification.

Keywords Integrated pest management - Agroecology · Conservation agriculture $\cdot$ Horticulture $\cdot$ Agroforestry

Contents

1. Introduction. . . . . . . . . . . . . 2

2. Bottom-up temporal cycle disruption of pests and pathogens via non-host effects............. 3

2.1. Hosts and non-host effects on pests and diseases. . 3 2.2. Examples of positive effects of introducing PSD. . 3

2.3. Examples of alternate host-associated negative

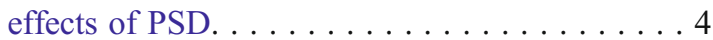


3. Bottom-up resource concentration/dilution and spatial disruption of pest dynamics/pathogen epidemics. . . . 5

3.1. Evidence of resource concentration/dilution effects. . . . . . . . . . . . . . 5

3.2. Evidence of spatial cycle disruption effects. . . .6 6

3.3. Drawbacks of species mixtures aiming at disruptive effects on crop pests/diseases. . . . . . . 6

4. Pest deterrence or repellence. . . . . . . . . . 6

4.1. Evidence of positive "deterrent diversion" effects. . . . . . . . . . . . . . . 6

4.2. Lack of evidence of positive "deterrent diversion" effects.................... 7

5. Pest stimulation or attraction. . . . . . . . . . 7

5.1. General principles and evidence of effectiveness of the trap cropping (or "stimulant diversion") strategy. . . . . . . . . . . . . . . 7

5.2. Limitations to the trap cropping strategy. . . . . 7

6. The "Push-Pull" strategy. . . . . . . . . . . . .8

6.1. Principles and instances of successful implementation. . . . . . . . . . . . . . 8

6.2. Limitations to the 'push-pull' principles. . . . . 99

7. Below-ground bottom-up allelopathic effects. . . . . 99

7.1. Trap crops/Suicidal germination inducers ..... . 9

7.2. Direct antibiotic effects during plant growth. . . 10

7.3. Antibiotic effect after biomass decomposition. . . 11

7.4. Limitations to the use of plants with allelopathic effects. . . . . . . . . . . . 12

8. Stimulation of soil pest-pathogen antagonists. . . . 12

8.1. Activation of general microflora and macrofauna................... 12

8.2. Activation of specific pathogen-antagonist microorganisms. . . . . . . . . . . . . 13

8.3. Instances of negative impacts of PSD via the soil pathogen antagonist pathway. . . . . . . . 13

9. Crop physiological resistance via improved nutrition. . . . . . . . . . . . . . . . . . . . . 14

9.1. "Tolerance/compensation"-like resistance. . . . . . 14

9.2. Non-preference (antixenosis)-like resistance. . . . 14

9.3. Antibiosis-like resistance. . . . . . . . . . . . . 15

9.4. Negative impacts of PSD resulting in increased disease incidence via the plant nutrition pathway. .................... 15

10. Top-down effects on crop pests via provision of alternative food. . . . . . . . . . . . . . . 15

10.1. Pollen and nectar food sources for pest parasitoids and predators. . . . . . . . . . 15

10.2. Shelters for alternate hosts and prey of pest parasitoids and predators. ............ 16
10.3. Instances where PSD negatively affects natural enemy populations and/or pest predation via provision of alternate food. . . . . . . . . 16

11. Refugia/shelters for predators due to vegetative structural/architectural characteristics. . . . . . . . 17

12. Positive and negative effects of PSD on pest and disease impact via microclimate alteration. . . . . . 17

13. Physical barrier effects on crop pests and diseases. . 19

13.1. Barrier effects against pests and pathogens at the field level. . . . . . . . . . . . . . . 19

13.2. Barrier effects against pests and pathogens at the landscape level . . . . . . . . . . . . . . . . 19

13.3. Negative impacts of barrier effects via natural enemy arrestment or facilitation of pest action. . . . . . 20

14. Conclusions and directions for future research on PSD-induced effects on pests and diseases. . . . . 20

14.1. Main lessons drawn from the literature review. . 20

14.2. PSD effects at the soil and field levels . . . . . . 20

14.3. PSD effects at the field and landscape levels. . . 23

14.4. Directions for future research. . . . . . . . . . 23

15. Acknowledgements. . . . . . . . . . . . . . . . 24

16. References .................... 24

\section{Introduction}

Farmers, particularly in the tropics, are faced with dramatic plant protection issues/phytosanitary risks resulting in:

- Food insecurity and reduced income in traditional lowinput agrosystems, e.g. in subsistence systems in SubSaharan Africa

- Adverse effects of pesticide use on human health and on the environment in and around intensive systems, e.g. in French overseas islands in the Caribbean, the Indian Ocean or the Pacific or in peri-urban horticulture in Africa

- Export restrictions due to strict regulations imposed by importing countries concerning quarantine pests and minimum limits on pesticide residues

To provide more and better food to populations in both the southern and northern hemispheres in a sustainable manner, there is a need for a shift from agrochemistry to agroecology. Agroecology is based on the optimization of biological interactions and regulations in agroecosystems, and its application to crop protection can be referred to as agroecological crop protection (Deguine et al. 2008).

The high vulnerability of modern intensive agroecosystems to crop damage by pests and diseases is classically ascribed to over-simplification of the systems (Tilman et al. 2002). The hypothesis that the resilience of these intensive agroecosystems can be increased simply by making their traits match 
those of natural ecosystems or of certain low-input, diversified, traditional agroecosystems was therefore proposed (Lewis et al. 1997; Dawson and Fry 1998; Jackson 2002).

Agroecosystem diversification at different scales is one of the two pillars of the agroecological approach, alongside soil quality enhancement (Nicholls and Altieri 2004; Ferron and Deguine 2005; Deguine et al. 2008). In addition to agronomic benefits (Malézieux et al. 2009), introducing vegetational diversity in agrosystems may lead to different pest and disease regulation processes.

But even though increased vegetational diversity and the general biodiversity it induces at different trophic levels lead to more efficient natural control of pests and diseases in agroecosystems in perhaps the majority of cases (Andow 1991), vegetational diversification per se is no guarantee of a reduction in the impact of pests and diseases (Helenius 1998). In addition, diversified systems are generally more difficult to manage than the simplified ones (Malézieux et al. 2009). Wood and Lenné (2001) suggest that some sustainable natural systems consist of simple vegetation with a single dominant species, e.g. wild relatives of rice, sorghum and wheat in simple, extensive, often annual stands.

Hence, there is a need for caution when recommending vegetational diversification to improve pest and disease control. A better understanding of the mechanisms involved is critical to explain how, where and when exceptions to this principle are likely to occur. In addition, tools are needed to evaluate, develop and monitor agroecosystems based on enhanced ecological processes of pest and disease control by optimized, rather than maximized, vegetational diversification or on "mimics" of such mechanisms if need be. Our review addresses these issues.

We do not include results of studies on weeds, except parasitic plants (Striga spp.) whose adverse impact on crops is closer to that of herbivore pests and pathogens, while weeds are basically competitors for the same resources. The effect of mixing crops on weed suppression is well documented (see, for example, Liebman and Altieri 1986; Weston 1996; Welsh et al. 1999; Hauggaard-Nielsen and Jensen 2005).

This review is limited to the interspecific, or "between species", dimension of vegetational diversification (from now on referred to as "plant species diversity", PSD), as opposed to its intraspecific, or genetic, dimension. Actually, there are already extensive reviews of the ways intraspecific crop diversity nearly always reduces yield losses caused by pathogens (Smithson and Lenné 1996; Zhu et al. 2000; Wolfe 2000; Finckh et al. 2000; Ngugi et al. 2001; Mundt 2002; Castilla et al. 2003; Cox et al. 2004), and sometimes by pests (Bush et al. 1991; Teetes et al. 1994; Johnson et al. 2006). Similarly, although addressed only marginally in the present review, we recognize intraspecific genetic variability in "service" or "companion" plants and the way such genetic variability can influence the effectiveness of pest management.
Integrating selected PSD plants in agroecosystems can reduce the impact of pests and diseases via several causal pathways either individually or in combination, namely: (1) pest-suppressing effects via visual and olfactory cues: resource dilution and stimulo-deterrent diversionary effects; (2) disruption of the spatial cycle via non-host effects; (3) a reduction in the inoculum/carry-over population thanks to the absence of a host plant: disruption of the temporal cycle; (4) below-ground bottom-up allelopathic effects; (5) stimulation of specific below-ground antagonists of pests/ pathogens or induction of general soil suppressiveness; (6) physiological resistance due to improved crop nutrition; (7) facilitation of top-down effects on aerial crop pests via natural enemy conservation and (8) direct and indirect architectural effects, including physical barrier effects and microclimate alteration (Fig. 1).

The relative importance of these effects depends on the crop pest/disease/natural enemy complex, e.g. "bottom-up", i.e. from a lower to a higher trophic level, vs. "top-down", i.e. from a higher to a lower trophic level, and belowground vs. aerial dispersal processes, the type of PSD and the scale of its implementation and effects, e.g. soil/plant, field, landscape.

\section{Bottom-up temporal cycle disruption of pests and pathogens via non-host effects}

\subsection{Hosts and non-host effects on pests and diseases}

Crop rotation with non-host plants is the first general agronomic rule to avoid soil-borne diseases, and tables of recommended rotations have been designed as decision support tools (Messiaen et al. 1991; Messiaen 1998). Nonhost effects via increased PSD at the field level over time disrupt the life cycle of soil-borne pests and diseases via below-ground processes. The major effect targeted is a reduction in inoculum or in carry-over population due to the absence of the host plant, but these prophylactic practices are not always effective, depending on the broadness of the host plant range or the existence of forms of conservation, e.g. in the case of the common scab of potato caused by Streptomyces scabies (Weinhold et al. 1964). Concerning aerial pests, some insects use different host plants as food in their larval stages from the plants they eat in their adult stage (Schoonhoven et al. 2006). Thus, a plant believed to be a non-host for an insect pest at one stage may turn out to be a host plant at another stage.

\subsection{Examples of positive effects of introducing PSD}

In the case of soil-borne diseases, using lucerne (alfalfa) as a break crop in cereal cultivation has been shown to influence 
Fig. 1 Major pathways for reducing the impact of pests and diseases via the introduction of plant species diversity in agroecosystems

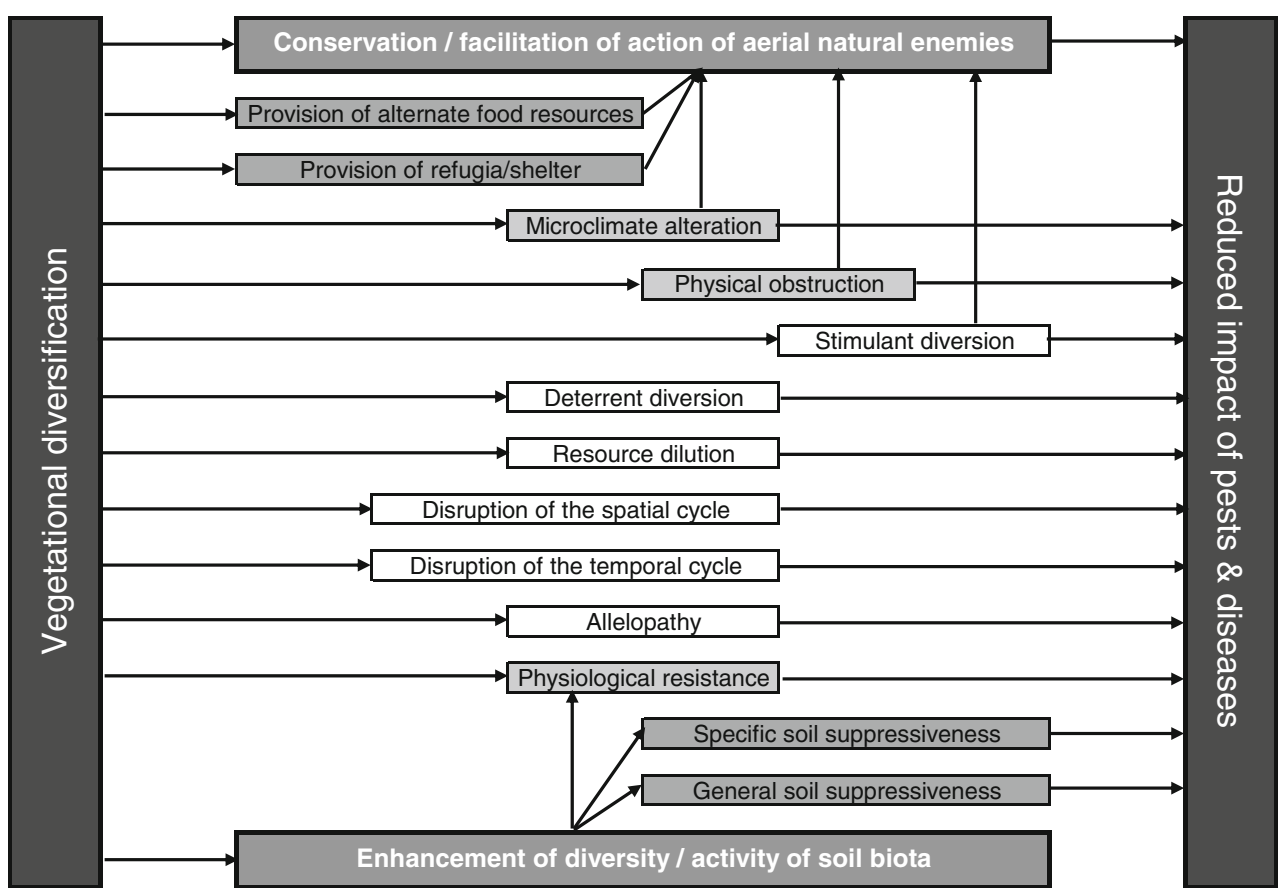

the inoculum potential of Fusarium culmorum and help prevent outbreaks of the disease (Knudsen et al. 1999). Avena strigosa and the hybrid Sorghum bicolor $\times$ Sorghum sudanense can be used for rotation with strawberries since these plants are poor hosts for Pratylenchus penetrans (LaMondia et al. 2002). Similarly, plants of the alliaceous family including onion (Allium cepa), garlic (Allium sativum) and Chinese chive (Allium fistulosum) (Fig. 2) are non-hosts for Ralstonia solanacearum (Fig. 3) and can reduce disease incidence (Yu 1999) and soil inoculum.

Although air-borne diseases can also be avoided to some extent through crop selection and crop rotations that include some non-host crops, this strategy is more effective for soilor residue-borne pathogens (Krupinsky et al. 2002) with reduced mobility and dispersal ability and a limited lifespan of conservation forms.

\subsection{Examples of alternate host-associated negative effects of PSD}

Cocoa (Theobroma cacao) grown under Leucaena shade suffered more from attacks of defoliating Lepidoptera than when it was grown under certain forest tree species because the pests were able to use Leucaena as an alternative food source (Room and Smith 1975). The same was true in the case of Moniliophthora roreri, the fungal pathogen which causes frosty pod rot disease in several species of the genera Theobroma and Herrania, including Theobroma bicolor and T. cacao (Evans et al. 2003) (Fig. 4). T. bicolor, which is often intercropped with cocoa trees, especially in Mexico, can be a source of inoculum for T. cacao.
Some pests sustain themselves on cover crops that thus serve as hosts and favour the build-up of infestation. In Benin, for instance, the cover plant species Canavalia ensiformis and Mucuna pruriens were found to be good alternative host species for the maize pest Mussidia nigrivenella (Schulthess and Setamou 1999). So, in this situation, the use of these particular cover crops was not advantageous.

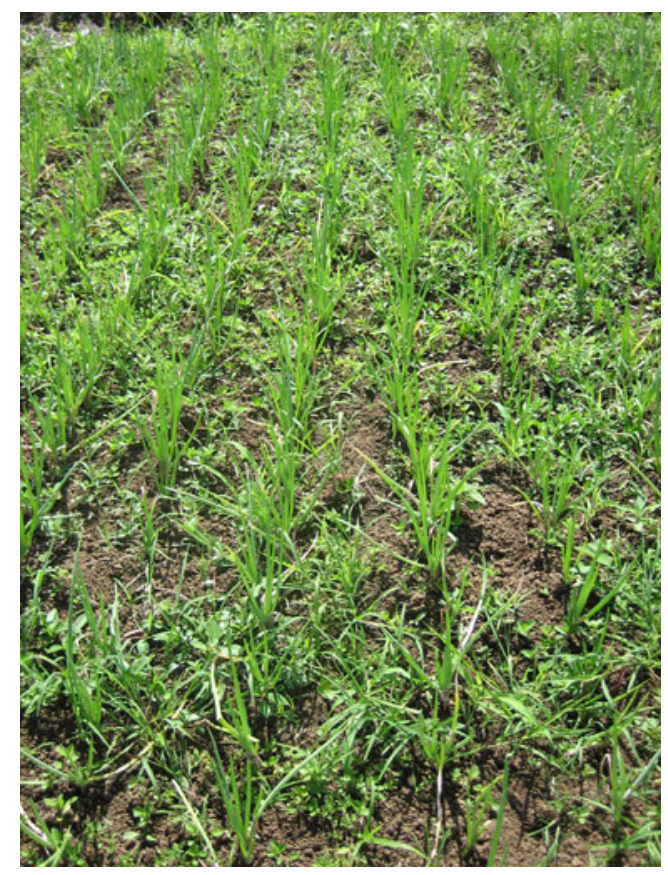

Fig. 2 Chinese chive (A. fistulosum) (Martinique) (C P. Fernandes, Cirad) 


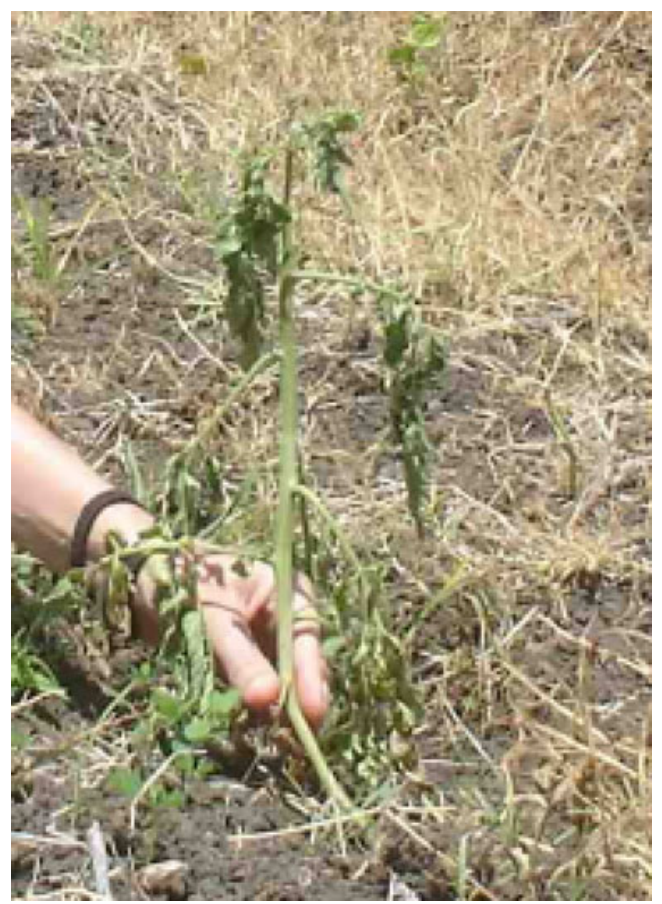

Fig. 3 Tomato bacterial wilt caused by $R$. solanacearum (Martinique) (C) A. Ratnadass, Cirad)

Similar complex relationships are also observed in rust diseases (Uredinales). Wheat stem rust caused by Puccinia graminis is a typical heteroecious rust which switches between common barberry (Berberis vulgaris) and cereals. Eradication of barberry in the USA reduced the risk of emergence of new wheat stem rust races through sexual

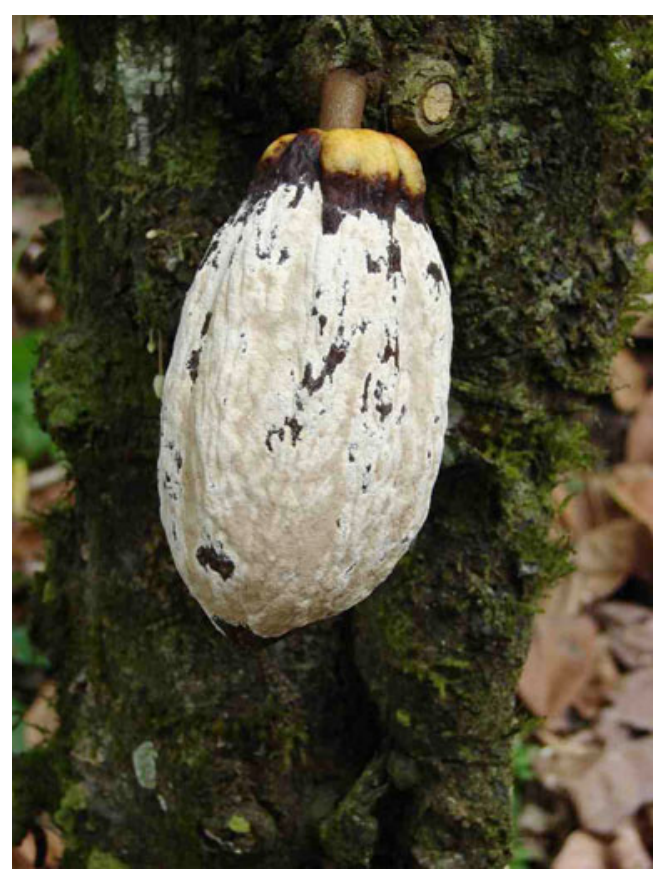

Fig. 4 Sporulating lesions of frosty pod rot of cocoa caused by $M$. roreri (Costa Rica) (C J. Avelino, Cirad) recombination. Eradication also reduced the occurrence of early, local epidemics caused by aecidiospores produced on barberry but infectious on cereals (Peterson et al. 2005).

The effects of host plants on insect populations may indirectly affect vector-borne diseases. This is the case of Pierce's disease on grapevine. The disease caused by the bacterium Xylella fastidiosa became particularly problematic in California after the introduction of a new vector, the leafhopper Homalodisca coagulata. This sharpshooter has the ability to disperse deeply into vineyards from neighbouring citrus fields (another host for $X$. fastidiosa) where it preferably overwinters and breeds. $X$. fastidiosa has a wide range of host plants, which includes wild, agricultural and ornamental plants, which also provides different hosts for $H$. coagulata (Almeida et al. 2005).

\section{Bottom-up resource concentration/dilution and spatial disruption of pest dynamics/pathogen epidemics}

\subsection{Evidence of resource concentration/dilution effects}

Most cultivated plants are derived from wild plants that are generally not visible to herbivores in a diversified plant community (Feeny 1976). Agriculture, which favours the concentration of a particular plant species, means plants that were formerly not very visible become highly visible in true plantations. Cultural practices such as high planting density and weeding particularly contribute to higher plant visibility for herbivores.

This visibility principle is similar to the "resource concentration" principle, which, in the case of monocrops, means that cues from the resource (crop plant) are no longer diluted by cues from other plant species (Root 1973). Monocropped plants are thus more visible than they would be in natural ecosystems or in systems based on intercrops (Feeny 1976). Phytophagous insects are thus more likely to find, and remain on, host plants growing in dense, nearly pure stands because a second plant species disrupts the ability of insects to efficiently attack their intended host (Asman et al. 2001).

This is particularly true for aerial pests since, from an above-ground perspective, the more non-host plants that are removed from a crop area the greater the chance that an insect will locate a host plant. For instance, bare soil cultivation, which eliminates all plants except the crop, ensures that it is exposed to the maximum insect pest attack possible in that particular locality (Collier et al. 2001). Conversely, there is evidence that, in high-trash situations, apterous aphid vectors are unable to identify their host and consequently colonization is reduced (A'Brook 1968). Studies on the influence of crop background on aphids and other phytophagous insects on Brussels sprouts 
suggest that the maintenance of some weed cover may be useful in the integrated control of some Brassica pests (Smith 1976).

For the same reason, polycultures usually support lower specialized herbivore loads than do monocultures (Helenius 1998; Altieri 1999). In particular, studies showed that the number of insect pests found on a brassica crop was considerably reduced when the crop was undersown with living mulch such as clover, which the authors attributed to the difficulty that the insects had in locating their host plant (Finch and Kienegger 1997; Finch and Collier 2000).

Plant species richness also tends to prevent the spread of viral infection in crops: $89 \%$ of plant viruses with a known transmission mechanism are transmitted by plant-feeding insects (Brunt et al. 1996). Greater plant species richness reduces the abundance of their insect vectors, and the majority of viruses that are transmitted by insects tend to be found at lower densities in polycultures than in monocultures (Power and Flecker 2008).

Banks (1998) ascribed the variability of results published in the literature to the different spatial scales at which the experiments were performed. Using mixtures of broccoli and weed patches in different proportions, he distinguished the effect of spatial scale from that of simple crop heterogeneity on crop herbivores. While cabbage aphids (Brevicoryne brassicae), which colonize crop patches from the air and are limited in their capacity for directed flight, were influenced by vegetation composition at all scales of fragmentation tested, cabbage butterflies (Pieris rapae), whose female moths are highly mobile with good sensory powers, were not affected by the scale or the composition, and flea beetles (Phyllotreta cruciferae), whose dispersal ability is intermediate, revealed a striking dependence on the scale of fragmentation and an interaction was found between the scale and the composition of the vegetation.

\subsection{Evidence of spatial cycle disruption effects}

The richness of crop species in an agroecosystem has a much less predictable effect on the prevalence of microbial pathogens that do not rely on insect vectors, such as the majority of fungi (Matson et al. 1997). However, an increase in species richness was shown to reduce the severity of host-specific foliar disease in 24 grassland plant species by reducing host density (Mitchell et al. 2002). These authors hypothesized that disease transmission decreased with a decrease in host abundance due to the interception of infectious propagules by non-host plants and the production of reduced quantities of inoculum, which is the principle used in multiline cultivars and cultivar mixtures.
In a way similar to that observed in mixtures of wheat cultivars, Vilich-Meller (1992) reported that wheat-barley mixtures resulted in greater disease reduction in wheat than did applications of fungicide, illustrating the potential benefit of mixing cereal species in organic agriculture (Kaut et al. 2008).

\subsection{Drawbacks of species mixtures aiming at disruptive effects on crop pests/diseases}

One of the main drawbacks of polycultures-when they involve non-harvestable cover crops or intercrops-is that the quantity of crop produced (although its quality may be improved due to lower incidence of pests and diseases) may be reduced considerably due to competition. Such conflicting effects were reported by Theunissen and Schelling (1996) in the case of leek when undercropped with clover (against onion thrips and leek rust), Smith (1976) in the case of Brussels sprouts with weed cover and Schellhorn and Sork (1997) in the case of collards interplanted with weeds.

\section{Pest deterrence or repellence}

These effects mainly involve bottom-up and trophic effects which can be used to control arthropod pests. The pests are deterred or repelled from the resource (the crop) by "push" stimuli which can be delivered by intercropping with nonhost plants with deterrent or repellent attributes that are appropriate for the target pest (Cook et al. 2007).

Compared to only non-host effects or only reduction in visibility (which are somehow "passive"), the effects reported in this section involve deterrent or repellent semiochemicals produced by a plant which is intercropped or undersown. With such "active" (and more likely effective) processes, the effects of competition may be compensated by the reduction in the impact of the pest, and in some cases, top-down effects may be superimposed on bottom-up effects.

\subsection{Evidence of positive "deterrent diversion" effects}

Uvah and Coaker (1984) attributed the reduced attacks on carrot mix-cropped with onion by carrot fly Psila rosae to the deterrent volatiles in onion plants. Also, observations of the flea beetle, $P$. cruciferae, indicated that tansy (Tanecetum vulgare) inhibited colonization by adults (Latheef and Ortiz 1984).

Kimani et al. (2000) showed that airborne volatiles from Melinis minutiflora repelled ovipositioning by the spotted stem borer on intercropped maize. In the repellent molasses grass and Desmodium, ocimene and nonatriene, which are 
semiochemicals produced during damage to plants by herbivorous insects (Turlings et al. 1990), were produced together with other sesquiterpenes.

It should be noted that, when molasses grass is intercropped with maize, it not only reduces infestation of the maize by stem borers but also increases stem borer parasitism by a natural enemy, Cotesia sesamiae, thus regulating pest populations via top-down effects (see "Section 6").

\subsection{Lack of evidence of positive "deterrent diversion" effects}

The "push" effect of some such plants may not be powerful enough to divert certain pests from the cultivated field or plantation. Even worse, some "push" plants may divert certain pests from the main crop while attracting others to it, which makes generalizations hazardous and fine-tuning based on the target pest or pest complex indispensable.

For instance, in herb intercropping experiments with Brassica, Latheef and Irwin (1979) found that none of the four species of pest caterpillars/butterflies studied was adversely affected by sage or thyme; and Dover (1985) stated that there is no scientific evidence that the odours from highly aromatic plants cropped as companion plants actually deter insect pests from a main crop like cabbage.

While Latheef and Ortiz (1983) found that while tansy decreased the number of eggs laid on crop plants by the cabbage looper Trichoplusia ni, these authors also found that it had the opposite effect on the cabbage worm $P$. rapae, namely, attraction (see "Section 5").

\section{Pest stimulation or attraction}

5.1 General principles and evidence of effectiveness of the trap cropping (or "stimulant diversion") strategy

Trap crops can be plants of a preferred growth stage, cultivar or species that divert pest pressure from the main crop because they are more attractive. Shelton and Badenes-Perez (2006) recently reviewed trap cropping and proposed a broad definition of trap crops as plant stands that are, per se or via manipulation, deployed to attract, divert, intercept and/or retain targeted insects or the pathogens they vector in order to reduce damage to the main crop.

Consequently, a thorough understanding of the behaviour of the pest and the way it is affected by the relative attractiveness of the trap crop compared with the main crop, the ratio of the main crop to the trap crop and its spatial arrangement (i.e. planted as a perimeter or intercropped trap crop), is crucial to the success of this strategy.
Among the ten successful cases of trap cropping at a commercial level, the orders of the targeted insect pests were Coleoptera, Heteroptera, Lepidoptera (three cases each) and Homoptera (one case). The cases of Coleoptera, Heteroptera and Lepidoptera involved insects that directed their movement and tended to aggregate in a highly attractive trap crop (Shelton and Badenes-Perez 2006).

Recent reports on the high potential of trap cropping based on field studies using PSD plants include the diamondback moth Plutella xylostella whose infestations in cabbage fields were reduced using yellow rocket (Barbarea vulgaris) as a trap (Badenes-Perez et al. 2005) and cotton bollworms Helicoverpa spp. whose infestations in cotton fields were reduced using field pea (Pisum sativum) in Australia (Grundy et al. 2004) and grain sorghum (S. bicolor) in the USA (Tillman and Mullinix 2004).

Dead-end trap crops are plants that are both highly attractive for egg laying by adult female pests and unfit for the development of their progeny, as described by Khan et al. (1997a), Shelton and Nault (2004) and Van den Berg (2006). Such trap crops serve as a sink for pests, preventing their movement from the trap crop to the main crop later in the season.

It should be noted that the dead-end properties of some trap plant species, e.g. absence of stem in Vetiver grass or trichomes on Napier grass (Figs. 5 and 6), may be enhanced by the action of the pest's natural enemies, although there are conflicting reports on the effects of plant trichomes on tritrophic interactions (Simmons and Gurr 2005; Styrsky et al. 2006). Even in the absence of such properties, increased predation on trap plants contributes to pest regulation without outside assistance. For instance, more parasitism by Trichogramma of Helicoverpa armigera was observed on sorghum (Fig. 7) than on other trap plants such as pigeon pea (Fig. 8) (Virk et al. 2004; Youm et al. 2005).

Although the main potential for the reduction in the impact of pests concerns aerial pests, there is some scope for this strategy in the management of below-ground pests like white grubs (by reducing pest pressure on the main crop) at the field level in direct seeding, mulch-based cropping (DMC) systems. For instance, the root system of kikuyu grass appears to reduce damage to geranium by the Hoplochelus marginalis white grub (Ratnadass et al. 2006b).

\subsection{Limitations to the trap cropping strategy}

The fact that, among the long list of plants that show potential for pest management via trap cropping, only a few have been used successfully at a commercial level (Shelton and Badenes-Perez 2006) is probably a sign that this strategy is tricky to implement. 


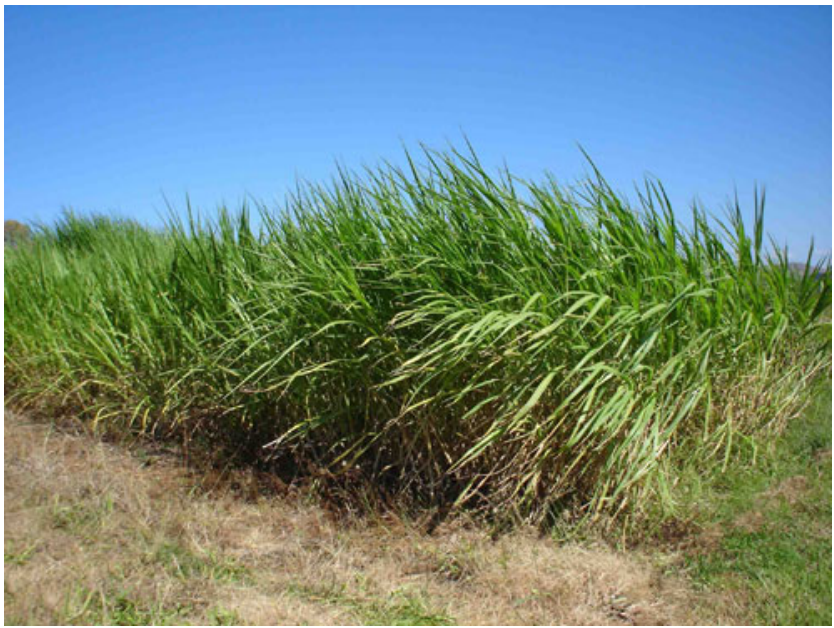

Fig. 5 Napier grass $P$. purpureum (South Africa) (C) A. Ratnadass, Cirad)

Conventional trap plants (Hokkanen 1991), which are merely attractants with no "dead-end" properties, may act first as "sinks" for pest populations and become sources of pests for the same field later in the season or for neighbouring fields (Hilje et al. 2001). Care should therefore be taken to avoid the above phenomenon by using other behaviour manipulation methods (Foster and Harris 1997).

On the other hand, dead-end trap crops may also end up selecting pest populations that will overcome this suicidal egg-laying behaviour (Thompson 1988; Thompson and Pellmyr 1991).

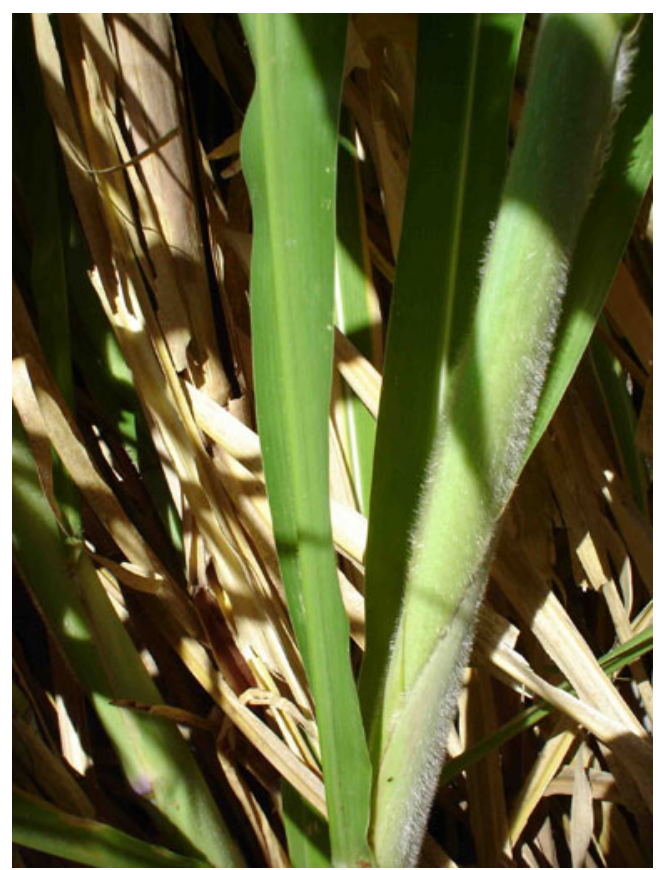

Fig. 6 Trichomes on Napier grass P. purpureum (South Africa) (C) A. Ratnadass, Cirad)

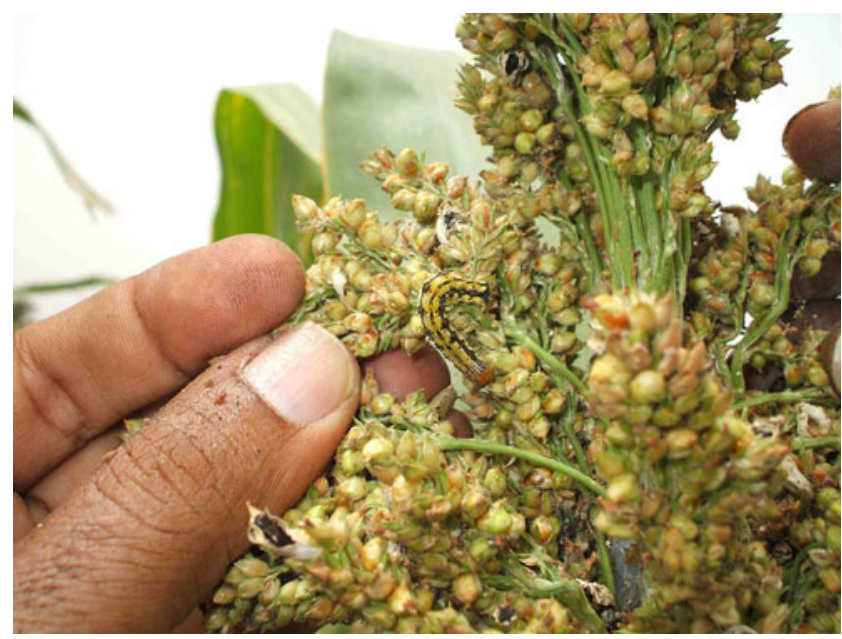

Fig. 7 H. armigera on grain sorghum: S. bicolor (Niger) (C A. Ratnadass, Cirad)

\section{The "push-pull" strategy}

\subsection{Principles and instances of successful implementation}

The "push-pull" strategy is a stimulo-deterrent diversion technique initially developed by Pyke et al. (1987) and Miller and Cowles (1990), whose principle consists in repelling the insect pest from the crop using repellent ("push") crops and attracting it to the border of the cropped field using trap ("pull") plants (Hokkanen 1991; Shelton and Badenes-Perez 2006; Cook et al. 2007).

This involves the combined use of trap and repellent plants in an attempt to optimize their individually partial effects. The main example of a successful application of the push-pull principles is that of stem borer management by the International Centre of Insect Physiology and Ecology (ICIPE) and its partners in Eastern Africa (Khan et al.

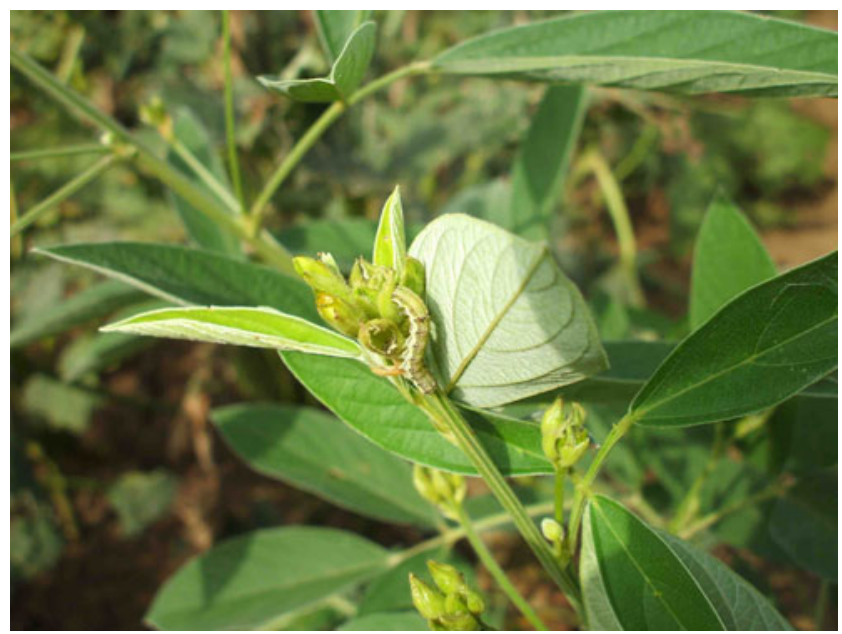

Fig. $8 H$. armigera on pigeon pea C. cajan (Niger) (C A. Ratnadass, Cirad) 
1997a, b, 2003), whereby stem borers were repelled from the maize (main) crop and were simultaneously attracted to the trap crop. Napier grass (Pennisetum purpureum) (Fig. 5) and Sudan grass (Sorghum vulgare sudanense) have shown good potential as trap plants, whereas molasses grass (M. minutiflora) and silverleaf desmodium (Desmodium uncinatum) (Fig. 9) repel ovipositing stem borers. The trap plants used in this association were deadend trap plants: they have the inherent property of inhibiting the development of the stem borers once they are trapped.

The principles of the push-pull strategy can be extended to the natural enemies of crop pests, with "top-down" effects, and instances of successful applications of the push-pull principles, e.g. by ICIPE and its partners in Eastern Africa, depend on mixtures of bottom-up and topdown effects (Khan et al. 1997a, b, 2003). Actually, repellent plants used as intercrops with maize in the pushpull strategy not only reduce infestation of the maize by stem borers but also increase stem borer parasitism by natural enemies.

The semiochemicals produced during damage to plants by insect pests, which mediate this behaviour of the pests and parasitoids, have been isolated (Khan et al. 1997a, b, 2003). Six active compounds were identified in trap plants: octanal, nonanal, naphthalene, 4-allylanisole, eugenol and linalool (Khan et al. 2000). In the repellent molasses grass and Desmodium, ocimene and nonatriene, i.e. semiochemicals produced during damage to plants by herbivorous insects (Turlings et al. 1990), were produced together with other sesquiterpenes. It is likely that, as these compounds are associated with a high level of stem borer colonization, they acted both as repellents to ovipositing moths and as foraging cues for parasitoids.

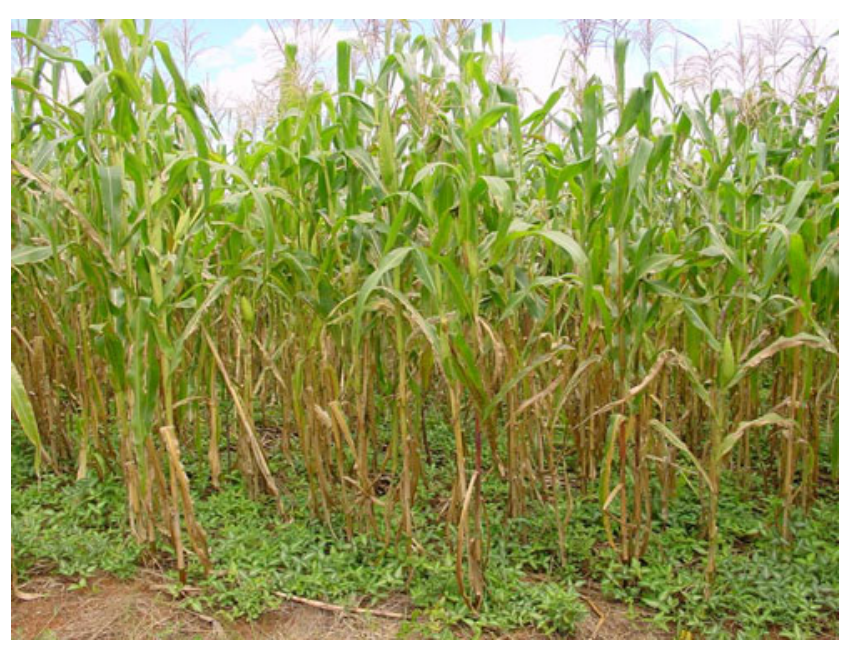

Fig. 9 Maize on a D. uncinatum live cover (Madagascar) (C O. Husson, Cirad)

\subsection{Limitations to the 'push-pull' principles}

The successful adoption by East African farmers of this push-pull technique cannot be ascribed only to the suppression of insect pests. Actually, Striga suppression by some "push" plants, via mechanisms which have nothing to do with those of stimulo-deterrent diversion (see "Section 7.1"), and the economic benefits of some push and trap plants as fodder crops largely contributed to its success, and the same reservations and incentives as for both plant deterrence and trap cropping should be taken into account before implementing the technique.

\section{Below-ground bottom-up allelopathic effects}

These are effects that directly affect the feeding/infection/ attachment ability of the pest or disease on the host plant. Several such effects can be distinguished depending on the type of pest. Various plants are known to produce and release antibiotic components via two major processes: (1) root exudation (see "Section 7.2") and (2) release of components during plant decomposition (see "Section 7.3") after incorporation in the soil.

\subsection{Trap crops/suicidal germination inducers}

Viable seeds of the witchweeds (Striga spp., parasitic plant species that dramatically affect cereal crop production in Sub-Saharan Africa), which may remain dormant in the soil for many years, will usually not germinate unless exposed to chemical compounds exuded from the roots of a host plant and certain non-host plants. One such compound, strigol, was isolated from the root exudates of cotton [a non-host plant for both Striga asiatica (Fig. 10) and Striga

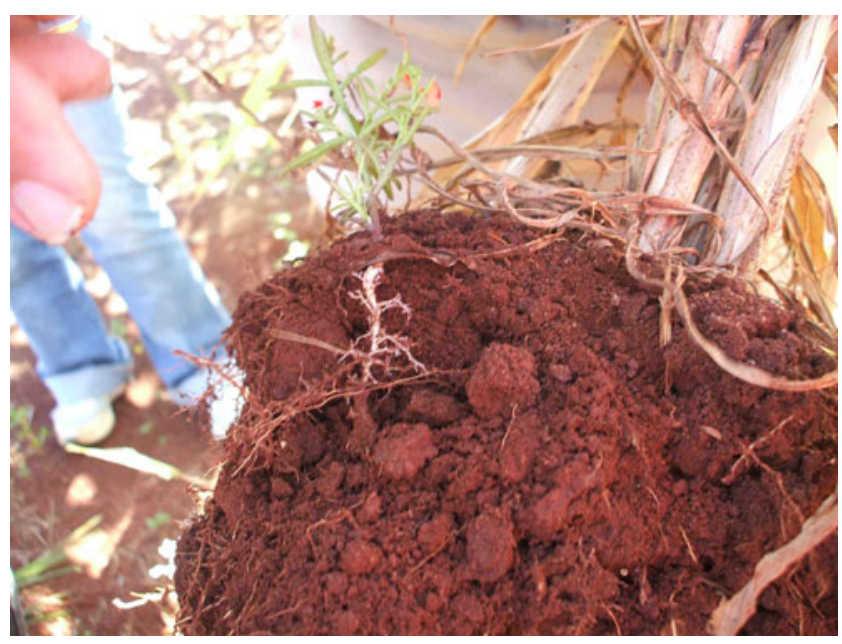

Fig. 10 Attachment of $S$. asiatica haustoria to upland rice roots (Madagascar) (C A. Ratnadass, Cirad) 
hermonthica (Fig. 11)] and has proved to be a powerful stimulant of witchweed seed germination (Vail et al. 1990; Pepperman and Blanchard 1985).

Such "trap" crops are effective and can be used to reduce soil seed banks and stimulate the suicidal early germination of Striga spp. seeds in a rotational strategy including both legume [e.g. soybean (Glycine max), Bambarra groundnut (Voandzeia subterranea), pigeon pea (Cajanus cajan) (Fig. 8), groundnut (Arachis hypogea), bean (Phaseolus vulgaris), cowpea (Vigna unguiculata), pea ( $P$. sativum), rattle-box/sunn hemp (Crotalaria spp.), lablab bean (Dolichos lablab)] and non-legume species [e.g. cotton (Gossypium hirsutum), sunflower (Helianthus annuus), castor bean (Ricinus communis), lin (Linum usitatissimum) and sesame (Sesamum indicum)] (Andrianaivo et al. 1998; Kayeke et al. 2007; Husson et al. 2008).

Other plants can be used as cover/fodder crops in DMC systems, e.g. Mucuna (Mucuna sp., Stizolobium atterrinum), Desmodium (Desmodium spp.) (Fig. 9) and Stylosanthes (Stylosanthes guianensis), which can stimulate $70 \%$ more Striga germination than maize without being parasitized (Ndung'u et al. 2000; Khan et al. 2008), Pueraria (Pueraria phaseoloides) or Callopogonium (Callopogonium тисиnoides) (Calegari and Ashburner 2003).

Khan et al. (2002) demonstrated a clear Striga allelopathic suppression effect by Desmodium. The mechanism involved both chemical stimulation of germination and inhibition of the development of $S$. hermonthica hyphae by at least two different isoflavanones released from Desmodium roots.

Regarding plant parasitic nematodes, Solanum sisymbriifolium (Lamarck), which was introduced in the Netherlands as a trap crop for potato cyst nematodes (Globodera spp.), stimulated hatching (although slightly less than the susceptible potato crop) but was completely resistant, i.e. no progeny

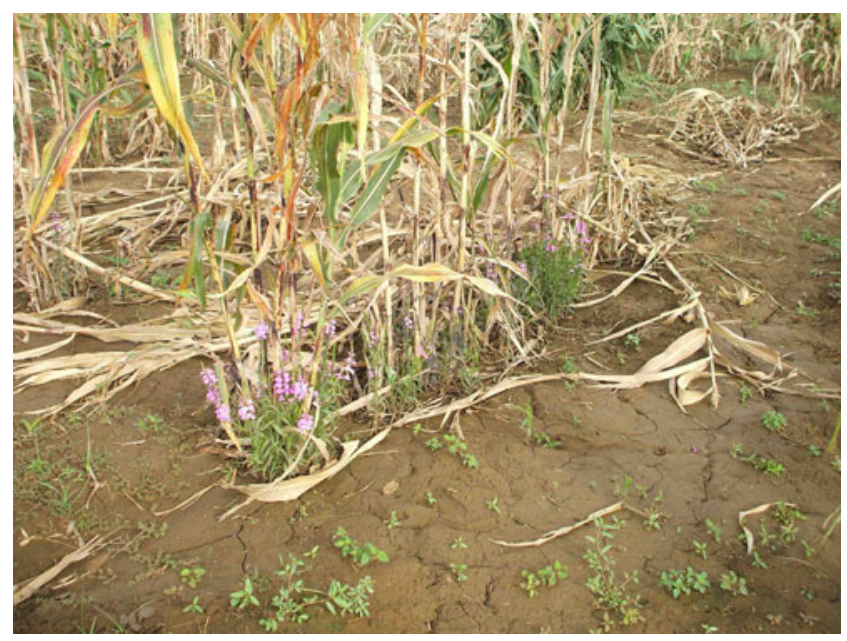

Fig. 11 S. hermonthica on sorghum (Niger) (C A. Ratnadass, Cirad) cysts were formed (Scholte 2000a, b; Scholte and Vos 2000; Timmermans et al. 2005).

Brassicaceous green manures can also act as trap crops for nematodes (Thorup-Kristensen et al. 2003). The best documented case of their use for this purpose is that of the control of sugar beet nematodes (Heterodera schactii) in Europe (Muller 1999; Schlathoelter 2004; Matthiessen and Kirkegaard 2006). In lieu of chemical control, cover cropping with resistant plants allows the sustainable production of sugar beet in fields infested with sugar beet cyst nematodes.

Fodder radish (Raphanus sativus) (Figs. 12 and 13) and white mustard (Sinapis alba) cover crops have been selected and developed to be grown as green manures preceding sugar beet crops (Caubel and Chaubet 1985; Lelivelt and Hoogendoorn 1993). The brassicas are invaded by the nematodes, which develop within the roots, but their sexual differentiation is disrupted. This results in very low numbers of females in the following generation, causing a significant decline in the population and reducing infestation of subsequent sugar beet crops.

This is a unique example related to specific nematoderesistant brassicas rather than a general non-hosting effect. Only the cultivation of resistant fodder radish and mustard varieties can lead to a reduction in the density of the population. All other varieties of these species contribute to a multiplication of the nematodes (Smith et al. 2004).

\subsection{Direct antibiotic effects during plant growth}

Other direct effects involve compounds that directly affect pathogen and pest survival (nematicidal, fungicidal or bactericidal compounds) or are feeding deterrents for insect pests with limited movement/dispersal ability (e.g. white grubs).

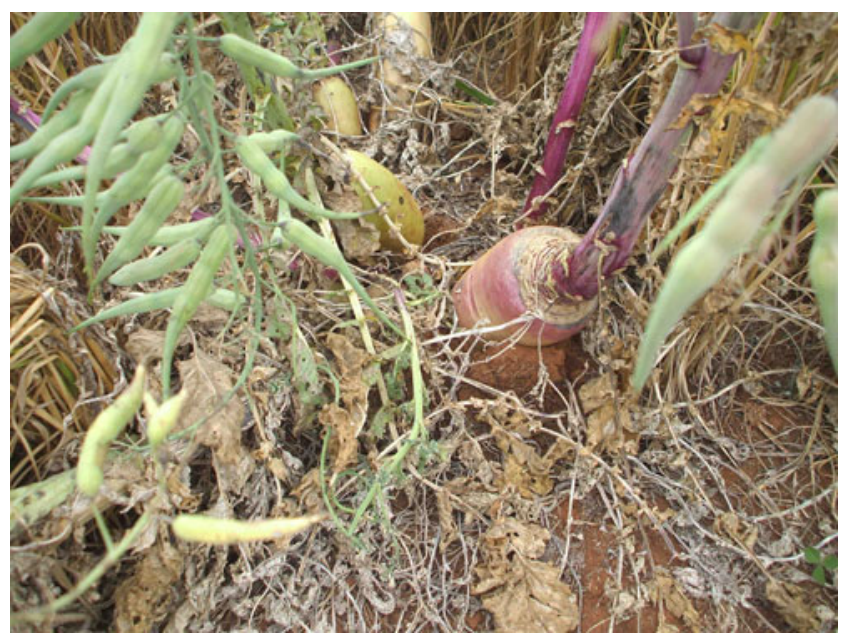

Fig. 12 Fodder radish R. sativus (Madagascar) (C A. Ratnadass, Cirad) 


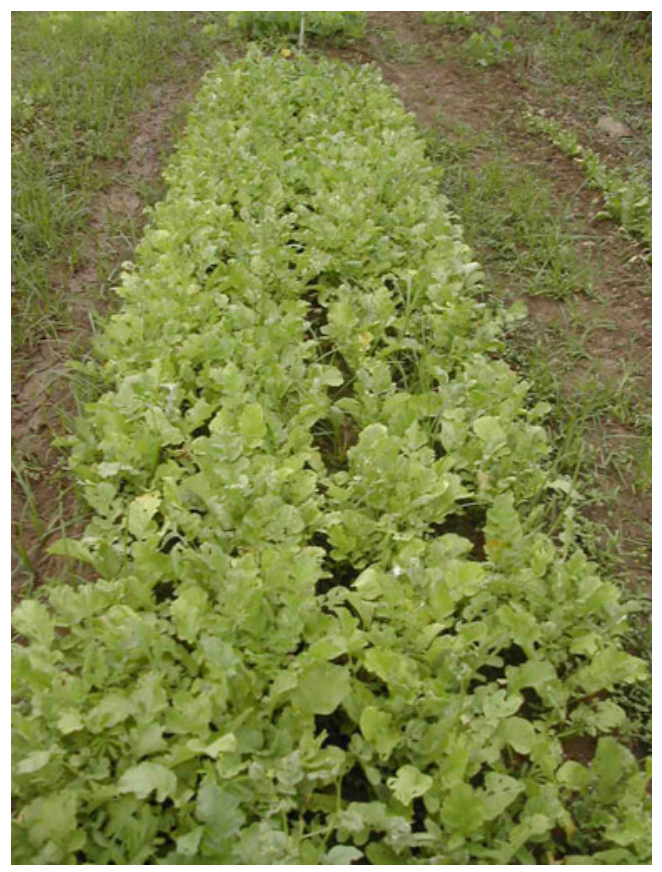

Fig. 13 Fodder radish R. sativus (Martinique) (C P. Fernandes, Cirad)

For instance, some nematicidal plants release toxic compounds that directly affect nematode mobility or hatching and other life processes (Gommers 1981). In the case of $A$. strigosa reported above, resistance to P. penetrans appears to be associated with increased production of avenocin (LaMondia et al. 2002).

Of the biocidal molecules released in the rhizosphere, alpha-terthienyl (from the Tagetes genus) was identified as being effective against a broad spectrum of phytoparasitic nematodes like Meloidogyne spp., Pratylenchus spp., Rotylenchulus reniformis (Dover et al. 2003). Tagetes patula was also found to reduce bacterial wilt caused by $R$. solanacearum (Terblanche 2002). Marigold (Tagetes erecta) also has allelopathic effects on the germination of Alternaria solani conidia. This effect is due to the presence of volatile thiophenes with biocidal properties in the marigold leaves (Gomez-Rodriguez et al. 2003). In the same botanical family, Zinnia spp. were identified as having nematicidal properties (Tiyagi et al. 1986).

Vicente and Acosta (1987) suggested a direct biocidal effect of Mucuna deeringiana roots on Meloidogyne incognita. Several molecules that had a nematicidal effect were then identified (Nogueira et al. 1996; Barbosa et al. 1999).

Tropical legumes like many species of the Crotalaria genus (particularly Crotalaria juncea and Cassia spectabilis) produce anti-nematode action via three mechanisms: (1) nemato-repellent compounds that affect larval development, (2) exudation of nemato-toxic compounds, pyrrolizidiniclike alkaloids such as monocrotaline, which are also present in leaves and seeds and (3) stimulation of antagonist microflora during plant decomposition (see "Section 7.3"). Differences in efficiency against $M$. incognita were also linked to the species of Crotalaria studied.

Some tropical grasses were shown to have both nematicidal and bactericidal properties. This was the case of a 2-year-old Digitaria decumbens, which reduced bacterial wilt due to $R$. solanacearum (Messiaen 1998) or a 4-month-old S. bicolor crop, which dramatically reduced the incidence of bacterial wilt. Oats and sorghum are also known to produce fungicidal root exudates, which are toxic to Fusarium, Gaeumannomyces and Rhizoctonia (Crombie and Crombie 1986; Odunfa 1978; Papavizas 1963).

Concerning white grubs/black beetles, studies in New Zealand revealed that root extracts from Lotus major (as opposed to two other Lotus spp.) contain a compound that is toxic to Costelytra zealandica and Heteronychus arator (Sutherland and Greenfield 1976). Similarly, growth of $H$. arator larvae was found to be greater on rye grass (Lolium perenne) and paspalum (Paspalum dilatatum) than on white clover (Trifolium repens). The reduced growth of $H$. arator on white clover was attributed to low consumption, probably thanks to the presence of feeding deterrents in the roots (King et al. 1981).

\subsection{Antibiotic effect after biomass decomposition}

A more indirect effect is that of cover or relay crops, or service plants with bio-fumigation potential, which takes effect after decomposition of the biomass. With the ban on methyl bromide, plant-parasitic nematode management has probably become a major incentive for the search for non-chemical methods and has inspired most research on sanitizing plants.

Isothiocyanates (ITCs) produced by Brassica crops are a well-known example of the release of biocidal components during plant decomposition. ITCs are known for their fungistatic activity (on Colletotrichum, Rhizoctonia, Fusarium, Phytophthora, Pythium, Gaeumannomyces, Aphanomyces) and bactericidal and nematicidal properties. During the decomposition of Brassica plants after mechanical disruption of the tissues, glucosinolates (GLS) contained in both root and shoot tissues are hydrolyzed by the enzyme myrosinase and produce different ITCs. These ITCs are chemically similar to metham sodium, a broadspectrum chemical soil fumigant.

The efficiency of biofumigation against soil-borne diseases depends mainly on the following factors: (1) the Brassica species used, which determines the type of ITC released (Sarwar and Kirkegaard 1998); (2) for a given Brassica species, the cultivar used, which determines both the GLS concentration in tissues and the total biomass 
produced, and hence the potential amount of GLS buried in the soil (Kirkegaard and Sarwar 1998; 1999); and (3) the timing of the destruction of the fumigant Brassica crop. To maximize biofumigation, it should be destroyed at the beginning of the flowering stage when biomass and GLS contents reach their maximum values (Sarwar and Kirkegaard 1998).

Sesquiterpenic acids like costic and isocostic acids found in Inula viscosa leaves are another example of biocidal molecules released during plant decomposition. These compounds have been shown to produce nematicidal activity at low concentrations, although the activity varied with the nematode species (Oka et al. 2001), Meloidogyne javanica being the most susceptible, followed by Tylenchulus semipenetrans, while Aphenlenchus avenae appeared to be resistant and Pratylenchus mediterraneus to be tolerant. Tolerance (like that of Pratylenchus) was also observed with thiarubrin, another nematicidal compound (Sanchez de Viala et al. 1998). The narrow activity spectrum of these molecules was confirmed on non-pathogenic nematodes like saprophytic nematodes, which continued to proliferate after decomposition. Other authors have reported that $I$. viscosa extracts possessed antifungal properties and could be used to control plant pathogenic fungi (Oka et al. 2001).

Onion and other alliaceous plants can also reduce soilborne diseases during their decomposition in the soil due to the release of sulphur compounds like dimethyl sulphide, carbon sulphide or dimethyl disulphide, the latter being the most effective molecule. Biocidal effects of these molecules have been reported in a range of soilborne nematodes: Meloidogyne sp., Heterodera sp, Ditylenchus sp. (Greco et al. 1986; Kanwar and Bhatti 1994; Leroux et al. 1996).

\subsection{Limitations to the use of plants with allelopathic effects}

Some Brassica crops commonly used for biofumigation to control root-knot nematodes have also been shown to be suitable hosts during their growing stage, thus leading to an increase in the pathogens prior to the biofumigation process (Bernard and Montgomery-Dee 1993; Mac Sorley and Frederick 1995; Mc Leod et al. 2001; Stirling and Stirling 2003).

However, this initial negative effect (the extent of which varies with the plant species and cultivar) can be reduced by sowing such susceptible crops during the cool season in subtropical climates. For instance, sowing at such low temperatures is effective in limiting the reproduction of a soil-borne nematode like M. javanica (Stirling and Stirling 2003).

Whatever the case may be, care should also be taken that the biofumigant does not affect beneficial soil organisms or natural enemies of targeted pests (see "Section 8"). In the case of biofumigation with Brassica crops, some authors reported no adverse effects on beneficial organisms. For example, Widmer and Abawi $(2000,2002)$ showed that bacterial-feeding nematodes were present in large numbers during the decomposition process. Free-living nematodes appeared to be less susceptible to toxins produced by Brassica crops than plant-parasitic nematodes (Stirling and Stirling 2003).

Although service plants with bio-fumigating properties may have a function in soil improvement as green manures, the same reservations as for non-harvestable repellent or trap plants may apply in the case of biofumigation.

\section{Stimulation of soil pest-pathogen antagonists}

\subsection{Activation of general microflora and macrofauna}

Actually, introducing a selected PSD may turn out to be a better option for building up beneficial populations than directly inoculating soil with beneficial microorganisms. For instance, Miethling et al. (2000) and Schloter et al. (2006) observed in the greenhouse that the plant sown (Medicago sativa and Secale cereale) had a stronger impact on rhizospheric microbial communities than soil inoculation with Sinorhizobium meliloti or the origin of the soil.

In some soils, disease suppressiveness is probably due to the activity of soil microbiota since suppressive soils consistently have higher populations of actinomycetes and bacteria than do soils conducive to diseases. The addition of organic material increases the general level of microbial activity (Wardle et al. 1995), and the more microbes there are in the soil the greater are the chances that some of them will be antagonistic to pathogens (Altieri 1999; Widmer and Abawi 2002) because organic inputs can improve the soil biological status by increasing both the diversity and the size of populations of beneficial species (McGill et al. 1986; Rasmussen et al. 1989; Rodriguez-Kabana and Kokalis-Burelle 1997). In this respect, rotating a variety of crops provides ecological niches for microorganisms and encourages microbial diversity.

Blanchart et al. (2006) reported higher densities of facultative phytophagous, bacterial-feeding and predatory nematodes and lower densities of obligatory phytophagous (Criconemella, Scutellonema and Meloidogyne) nematodes, resulting from intercropping maize with $M$. pruriens.

Blum and Rodriguez-Kabana (2006) found that addition of extracts of velvetbean (M. deeringiana) to soils decreased the incidence of southern blight in soybean (caused by Sclerotium rolfsii), while increasing the general bacterial population, particularly Bacillus megaterium, Enterobacter aerogenes and Pseudomonas putida, while addition of extracts of kudzu (Pueraria lobata) increased 
both fungal and bacterial populations, particularly Trichoderma koningii, Penicillium citreonigrum and P. herquei fungi and B. megaterium, E. aerogenes and $P$. putida bacteria. In particular, the population of $P$. putida was found to be negatively correlated with disease incidence.

Similarly, Zhou and Everts (2007) attributed the suppression of Fusarium oxysporum wilt disease of Citrullus lanatus to an increase in the bacterial population in soils where hairy vetch was ploughed in.

PSD-induced stimulation of soil biological activity may also apply to soil macrofauna. High organic matter accumulation from diversified biomass results in higher macrofaunal diversity, particularly that of decomposer taxa, at the expense of herbivore/root-feeding species (Brown and Oliveira 2004). Brévault et al. (2007) reported in Cameroon increased diversity and activity of soil macrofauna under no-till systems with grass (Brachiaria ruziziensis) and legume (Crotalaria retusa and M. pruriens) mulches compared to conventional tillage. Direct-seeded mulch-based systems were shown to favour the establishment of detritivores (earthworms, termites, ants) and predators (spiders, carabids, staphylinids, centipedes).

Recent research in Brazil distinguished different subfamilies of Scarabaeidae. Dynastinae larvae (white grubs) normally feed on organic matter and rarely on roots, while those of Melolonthinae feed mostly on roots and less on organic matter. Root-feeding species become predominant in soils where biodiversity has been reduced in comparison with species that decompose litter and other organic matter and do little damage to roots (Brown and Oliveira 2004). More recent research in Madagascar suggests another effect of litter/biomass accumulation, which not only results in the "inversion" of the faunal composition described above but in some instances in a change in the status of some pests, e.g. white grubs. Some species did not damage rice plants even in soils with low crop residues/organic matter content, whereas other species did damage rice plants even in soils with high crop residue contents, while most other species behaved either as pests or as detritivores, depending on the crop residue content of the soil (Ratnadass et al. 2006a). Such plasticity in certain scarab beetle species was already reported several decades ago (Ridsill Smith 1975).

\subsection{Activation of specific pathogen-antagonist micro-organisms}

It is important to understand the effects on soil organic matter of the biochemical characteristics of antibiotic plants (Palm and Rowland 1997) such as lignin, cellulosis, hemicellulosis, organic soluble fraction and polyphenol contents after ploughing, the persistence of these effects (Paustian et al. 1997), their decomposition kinetics and their impact on the structure of bacterial and fungal populations (Davet 1996).
In addition to direct antibiotic effects ("Section 7"), some plant species can also stimulate antagonists in the rhizosphere (Klopper et al. 1992; 1999; Insunza et al. 2002). Tropical legumes of the genus Crotalaria may thus induce an increase in the abundance of chitinolytic organisms and modifications in nematode communities, especially the development of bacterial- and fungal-feeding nematodes (Wang et al. 2004, 2006).

For instance, the rhizosphere of some nematicidal plants like Plantago major and Thymus officinalis not only releases nematicidal compounds but also harbours nematode-antagonistic bacteria (Insunza et al. 2002). These bacterial isolates produce hydrolytic enzymes, some of which are related to soil suppressiveness such as chitinase (which is reported to destroy the chitinous layer of nematodes) and chitinolytic bacteria (which are reported to be effective biological agents for the control of nematodes) (Spiegel et al. 1991; Tian et al. 2000) and also proteases.

The chemical composition of organic matter inputs such as plant residues and their specificities thus influences the efficiency of the suppression of soilborne diseases (Van Bruggen and Grunwald 1996). For instance, organic matter inputs that are rich in chitin will stimulate chitinolytic microflora, a group which also contains species that are antagonistic to phytoparasitic nematodes and fungi (Rodriguez-Kabana and KokalisBurelle 1997). Phenolic compounds (tannins) contained in organic matter with a high $\mathrm{C} / \mathrm{N}$ ratio also have a suppressive effect on fungi (Kokalis-Burelle and Rodriguez-Kabana 1994) and nematodes (Mian and Rodriguez-Kabana 1982). The more complex the residue, the more diverse the species involved in its decomposition.

\subsection{Instances of negative impacts of PSD via the soil pathogen antagonist pathway}

The take-all disease of wheat caused by the soil-borne pathogenic fungus Gaeumannomyces graminis var. tritici provides a counter-example since the trend to an increase in the incidence of the disease observed after a few years of monoculture of susceptible wheat cultivars may be reversed after another few years. A phenomenon of soil resistance to the disease (called take-all decline, TAD) appears to occur. Furthermore, suppressiveness can be reduced or eliminated by breaking monoculture with a non-host crop (Cook 1981).

Several lines of evidence support the widely held opinion that different microbial antagonists and mechanisms are responsible for TAD worldwide (Weller et al. 2002). One of these is fluorescent Pseudomonas spp., which produces the fungicidal compound 2.4-diacetylphloroglucinol (Sarniguet et al. 1992a, b; Weller et al. 2002). Fluorescent Pseudomonas spp. that produce 2.4-DAPG inhibit many different plant 
pathogens and are enriched in other suppressive soils, especially those with a history of monoculture (black rot of tobacco; crown and root rot of tomato; Pythium damping-off of cucumber, wheat, sugar-beet and pea; Pythium root rot of wheat; cyst nematode and soft rot of potato) (Weller et al. 2002).

\section{Crop physiological resistance via improved nutrition}

\section{1 "Tolerance/compensation"-like resistance}

In addition to their nematicidal activities, Crotalaria species (particularly Crotalaria juncea, a productive legume) also increase the yield of the following crop due to improved soil nitrogen status (Wang et al. 2003). Varied crop rotations contribute to better and more balanced soil fertility to support crop growth because each crop species has different nutritional requirements for optimum growth and development, and each draws on individual nutrients in the soil at different rates. This balance has been suggested to have a positive effect on crop resistance to pests and diseases (Krupinsky et al. 2002).

An indirect positive effect of mulching and of the use of cover crops is thus better crop nutrition from minerals derived from the decomposition of organic matter, provided biofumigants with antibiotic effects on beneficial microorganisms are not released (see "Section 7.4"). Mulching also limits evaporation and contributes to better water nutrition of crops (Scopel et al. 2004), making them better able to withstand attacks by pests or pathogens [e.g. rice to Striga or rice blast (Fig. 14) caused by Magnaporthe grisea (=Pyricularia oryzae)] (Husson et al. 2008; Ou 1985; Sester et al. 2008).

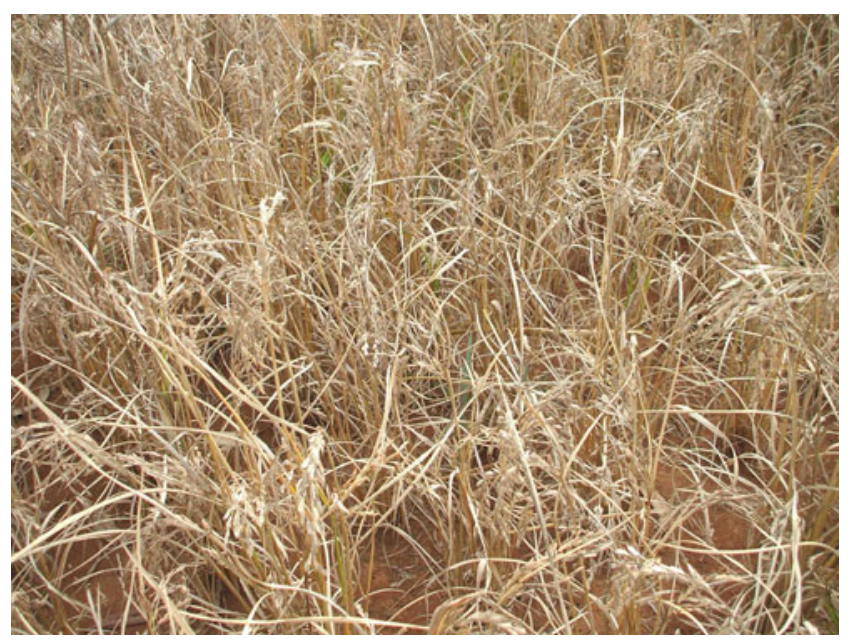

Fig. 14 Rice blast caused by M. grisea (=P. grisea) (Madagascar) (C) A. Ratnadass, Cirad)
However, undercrops may also compete with the main crop for water (Malézieux et al. 2009). On the other hand, Kvedaras et al. (2007) found that silicon (Si) provided greater protection against attacks by the sugarcane stem borer Eldana saccharina in water-stressed cane than in unstressed cane (see also "Section 9.3").

\subsection{Non-preference (antixenosis)-like resistance}

According to the theory of trophobiosis developed by Chaboussou (2004), nitrogen-induced susceptibility to some diseases may be linked to high amino acid contents in plant tissues and to reducing sugars, which facilitate the development of pathogens. Agricultural practices that lead to significant discrepancies in nitrogen availability (in terms of quantity, form and balance with other nutrients) are likely to result in variations in the incidence of diseases such as rice blast (Primavesi et al. 1972; Séguy et al. 1981, 1989; Long et al. 2000; Walters and Bingham 2007). High concentrations of these compounds in plant cells also make them more attractive to certain pests, particularly sucking insects (Chaboussou 2004; Jahn et al. 2005; Lu et al. 2007).

Like for insect pests, variations in herbivore response to in planta $\mathrm{N}$ content may be explained by differences in the feeding behaviour of the herbivores themselves (Pimentel and Warneke 1989). For example, populations of sucking insects were found to increase with increasing nitrogen concentrations in creosotebush (Larrea tridentata) plants, whereas the number of chewing insects declined (Ohmart et al. 1985).

With higher nitrogen fertilization, the amount of nutrients in the plant increases, as does the amount of secondary compounds, which may selectively affect herbivore feeding patterns. Thus, protein digestion inhibitors that accumulate in plant cell vacuoles are not consumed by sucking herbivores but will harm chewing herbivores (Mattson 1980; Letourneau et al. 1996).

More balanced soil fertility due to increased diversity of cropping systems should thus help reduce the incidence of pests and diseases via trophobiosis (Chaboussou 2004). However, as a general rule, in systems like agroforestry or DMC systems, much of the $\mathrm{N}$ that is not taken up by the crop is incorporated in the soil organic matter and is only gradually released through mineralization. Consequently, luxury consumption of $\mathrm{N}$ and reduced pest and disease resistance of the crops as a result of biomass applications would not normally be expected (Schroth et al. 2000).

On the other hand, as nutrition (notably $\mathrm{N}$ nutrition) also influences crop yield and quality, a balance must be found between maximizing yield and quality and minimizing disease. For instance, organic matter-based nutrients provided by systems such as organic farming or DMC systems, 
although released in a balanced and regular manner (Ratnadass et al. 2006b), are predominantly N-limited, and the main problem is timing the release of $\mathrm{N}$ so that it is available when crop demand is greatest (Walters and Bingham 2007), e.g. at the time of litter decomposition (particularly in the case of a high $\mathrm{C} / \mathrm{N}$ ratio) in $\mathrm{DMC}$ systems (Sall et al. 2003).

\subsection{Antibiosis-like resistance}

Some minerals present in certain PSD plants may confer specific resistance to particular pests or diseases. Manganese $(\mathrm{Mn})$ is a nutrient associated with increased resistance to a number of crop diseases, whose availability is affected by crop rotation. Mn inhibits the induction of aminopeptidase, an enzyme which supplies amino acids that are essential for fungal growth, and pectin methylesterase, a fungal enzyme that degrades host cell walls. Mn controls lignin and suberin biosynthesis through activation of several enzymes of the shikimic acid and phenylpropanoid pathways. Both lignin and suberin are important biochemical barriers to fungal pathogen invasion since they are phenolic polymers resistant to enzymatic degradation (Dordas 2008). It was shown that crop rotation with lupins increased the availability of $\mathrm{Mn}$ (Graham and Webb 1991).

This is also the case of Silicon ( $\mathrm{Si}$ ), which confers resistance not only to diseases (Datnoff et al. 1997; Rodrigues et al. 2003) and pests in rice (Voleti et al. 2008) but also to stem borers in sugarcane (Kvedaras et al. 2005; 2007). While it remains to be established whether PSD-induced resistance could be achieved by rotation or mulching with plants whose root systems draw on nutrients present in deep soil layers, such rotations with non-Siaccumulating crops would certainly delay the depletion of $\mathrm{Si}$ available to crops like rice and maintain crop productivity better than continuous cropping (Walters and Bingham 2007).

9.4 Negative impacts of PSD resulting in increased disease incidence via the plant nutrition pathway

The satisfactory nutritional status of the host is no guarantee of high physiological resistance. There are contradictory reports about the effects of nutrition on plant diseases probably because these effects depend on so many different factors (Walters and Bingham 2007; Dordas 2008). In particular, they depend on the infection strategy of the parasite. In the case of necrotrophic pathogens, which prefer senescent tissues and are able to break down host cells to obtain their nutrients, good mineral nutrition may favour host resistance. On the other hand, good host nitrogen nutrition favours the development of biotrophic parasites, which feed and reproduce in living cells throughout a long and intimate relationship with the host. For example, for Puccinia striiformis f.sp. tritici on winter wheat (Neuman et al. 2004), the severity of the disease was shown to increase after nitrogen supplies.

Although generally associated with mineral fertilization, such a phenomenon may also be observed with PSDderived organic matter. For instance, in an alley cropping experiment in Mindanao (Philippines), lower yields with a higher number of empty grains of rice in agroforestry plots than in the agricultural controls were explained by the increased incidence of blast (Maclean et al. 1992). The disease apparently counteracted the positive effects of the hedgerow biomass on crop development as evidenced by increased tiller and panicle numbers and increased plant height. As the incidence of blast in upland rice is increased by high $\mathrm{N}$ supply, the authors concluded that the amount of N-rich biomass applied to this crop needs to be controlled.

\section{Top-down effects on crop pests via provision of alternative food}

PSD-induced top-down regulation of crop pests is one aspect of conservation biological control. Although this may involve facilitation of natural enemy populations at a local level, Schmidt et al. (2004) and Tscharntke et al. (2007) stressed the need for a landscape approach to conservation biological control in agroecosystems. PSD effects on pest natural enemies follow different causal pathways. In this and in the following section ("Section 11"), we discuss pathways involving regulation by parasitoids and predators, while other pathways are addressed in "Sections 12 and 13 " as they are linked with effects of microclimate and connectivity.

10.1 Pollen and nectar food sources for pest parasitoids and predators

Wild habitats shelter a wide range of natural enemies of crop pests, including predators like ground beetles, staphylinids, spiders, ladybirds, hoverflies, lacewings, predatory bugs, predatory mites and parasitoids (van Emden 1965).

In particular, habitats comprising perennial and annual vegetation located outside cropped fields can serve as a source of pollen and nectar, which are critical food components for many insects (Bianchi et al. 2006). For instance, parasitoid longevity and fecundity are significantly increased when nectar is available (Baggen and Gurr 1998; Tylianakis et al. 2004). It has been shown that lacewings, ladybirds, hoverflies and parasitoids, which control pest populations in cropped fields, use sources of nectar located outside these fields (Hickman and Wratten 1996). 
Regarding within-field PSD, Mailloux et al. (2010) studied the influence of ground cover and its management on the diversity and density of phytoseiid mites (potential predators of the citrus rust mite and the broad mite in Guadeloupean citrus orchards). They attributed the increase in the density of phytoseiid mites to a variety of factors including the provision of food resources such as pollen and nectar, which, in the case of the Neonotonia wightii cover crop, are probably due to plant characteristics (notably pilosity) that increase their ability to capture wind-blown pollen grains.

On the other hand, Vollhardt et al. (2008) found that arable fields in high-intensity agricultural landscapes with little non-crop area could support a similar diversity of cereal aphid parasitoids as structurally complex landscapes, suggesting that cereal aphid parasitoids may find necessary resources even in simple landscapes, which makes it difficult to generalize about the relationship between landscape composition and biodiversity in arable fields. The discrepancy between cereal aphid parasitoids and other natural enemies like spiders (Schmidt et al. 2005) can partly be ascribed to life history traits and specific adaptations, i.e. the fact that cereal aphid parasitoids may not require alternative vegetation as overwintering sites and that parasitoids of honeydew-producing arthropods could have evolved adaptations to optimize exploitation of this food as a substitute for pollen and nectar (England and Evans 1997; Vollhardt et al. 2008; Wäckers et al. 2008).

10.2 Shelters for alternate hosts and prey of pest parasitoids and predators

Wild perennial and annual vegetation may also shelter alternate hosts and prey for parasitoids and predators of crop pests (Bianchi et al. 2006). According to Landis and Menalled (1998), over $60 \%$ of the alternative hosts of the generalist parasitoids controlling herbivorous caterpillars on maize, soybean, wheat and alfalfa are also pests of trees and shrubs. The presence of hosts and alternative prey may increase populations of parasitoids and predators (at least of generalist species) before the arrival of the target pest, leading to improved control of the pest.

An example of such "apparent competition", which ecologists call "negative prey-prey interaction", was described by Östman and Ives (2003). These authors reported that lucerne (alfalfa) fields with high densities of the pea aphid Acyrthosiphon pisum attracted more Nabid predatory bugs, resulting in higher predation rates on the potato leafhopper Empoasca fabae. Prasifka et al. (2006) also reported higher predation of the European corn borer by ground beetles in a rotation of maize and soybean with living mulches of forage crops (kura clover and lucerne) compared to no-mulch controls, which was mainly attributed to consumption of sentinel prey.
10.3 Instances where PSD negatively affects natural enemy populations and/or pest predation via provision of alternate food

Some species of Phytoseid mites, particularly general predators of the genus Euseius, play a significant role as control agents of spider mites, thrips and even white flies and can reproduce on pollen at a rate as high as on prey (McMurtry and Croft 1997). Pollen from windbreaks has been suggested to be important for building up populations of Euseius species, but in turn the presence of plant resources could result in decreased predation.

As a matter of fact, in the case of predation by true omnivores (i.e., those that consume both plant material and animal prey within a single life stage), the presence of plant resources can increase or decrease predation depending on the degree to which they are complementary to, or can be a substitute for, the prey. For instance, Robinson et al. (2008) found that, in a model comprising an omnivorous adult lacewing (Micromus tasmaniae), buckwheat flowers and aphid prey maintained on broad bean, floral resources mediated omnivore-prey relationships with either positive or negative effects on biological control. On the one hand, flowers reduced consumption of the prey but not lacewing fecundity when aphids were provided in abundance; on the other hand, when aphids were less abundant, providing flowers decreased the pre-oviposition period and increased the daily oviposition rate; also, in the absence of prey, longevity was higher in lacewings with access to flowers than in those without.

In any case, as flowering plants provide supplementary food not only for natural enemies of pests but also for the crop pests themselves, the composition of flora in non-cropped habitats is critical in determining which type of effect is to be expected (favouring crop pests or their natural enemies) (Baggen and Gurr 1998; Landis et al. 2000; Colley and Luna 2000; Lavandero et al. 2006).

On the other hand, as opposed to "negative prey-prey interaction", what ecologists call "positive prey-prey interaction" negatively affects biological pest control. This happens when an alternative prey diverts predation exerted by a natural enemy away from the target pest, thus protecting the latter. For instance, Halaj and Wise (2002) found that, in vegetable gardens, plots with the highest densities of alternative hosts (namely detritivores) and the highest densities of associated predators did not have lower densities of pests. In this case, predators prefer to feed on detritivores, which "protect" herbivores from increased predation.

Similarly, predaceous mites were found to be more abundant in soils containing large amounts of cover crop residues but these predators were not correlated with lower populations of symphylan pests. Cover crops increased 
both the ratio of predaceous mites to symphylans and the total population of potential prey, thereby reducing the capacity of predaceous mites to regulate symphylan populations (Peachey et al. 2002).

\section{Refugia/shelters for predators due to vegetative structural/architectural characteristics}

From the point of view of biocontrol, the general function of shelter habitats is to provide beneficial arthropods with semi-permanent habitats with suitable biotic and abiotic conditions for overwintering, aestivation and reproduction and a refuge from the perturbations of farming practices (e.g. ploughing, spraying, harvesting) (Griffiths et al. 2008). Shelter habitats also provide readily accessible cover from aerial predators (Lima 1993) and safe travel corridors for cryptic species that rarely venture far from dense cover (Rypstra et al. 1999; Halaj et al. 2000).

For instance, in a study by Mailloux et al. (2010) on the influence of ground cover and its management on the diversity and density of predatory phytoseiid mites in Guadeloupean citrus orchards (see "Section 10.1"), an increase in phytoseiid mite densities was partly ascribed to microclimate buffering (namely lower temperatures and higher humidity with reduced daily variations) in the ground cover crop, protection from macro-predators and, particularly in the case of the $N$. wightii cover crop, an increase in the number of oviposition sites due to plant characteristics, particularly pilosity.

Another example of facilitating PSD-induced predator efficiency is the addition of sunflower intercrops, which was shown to be an effective way of modifying the habitat to increase the number of avian insectivores and insect foraging time spent in organic vegetables. This was mainly ascribed to the provision of high-visibility perches for prey among the crop vegetation (Jones and Sieving 2006).

In addition, some agroforestry shade trees may provide nesting substrates for ants, thus creating complex mutualism/ antagonistic chains that may affect crop pests and diseases in several different ways. For instance, studies conducted by Perfecto and Vandermeer (2008) in a coffee agroforestry system in Costa Rica on mutualism between the ant $A$. instabilis and the scale insect $C$. viridis provided insights into the consequences of the spatial pattern of the scale insect on coffee bushes for the stability of predator-prey (hostparasitoid) systems, for a key coccinelid beetle preying on the scale insects and a phorid fly parasitoid parasitizing the ants. In addition, a spatial correlation between the attack of the entomogenous fungus Lecanicillium lecani on the scale insect and the incidence of coffee rust suggested a hyperparasitic effect of $L$. lecanii on $H$. vastatrix enhanced by the ant-coccid mutualism (Vandermeer et al. 2009).

\section{Positive and negative effects of PSD on pest and disease impact via microclimate alteration}

Although fungal diseases are usually less severe in polycultures than in monocultures, variations occur due to a variety of factors that influence the effects of intercropping on disease dynamics, including microclimate (Boudreau and Mundt 1997). Crop diversification can alter microclimate in ways that either encourage or inhibit pathogen growth, depending on the characteristics of the pathogen, the plants and the local environment (Boudreau and Mundt 1997).

Effects of PSD on microclimate have been described in annual and perennial crops alike. For instance, intercropping marigold (T. erecta) with tomato (L. esculentum) reduced the length of the period with more than $95 \%$ relative humidity, creating adverse conditions for conidial development of $A$. solani (the fungal pathogen that causes early blight disease in tomato) (Gomez-Rodriguez et al. 2003).

Conversely, Leroi et al. (1990) reported increased infestation of cowpea by bruchid Bruchidius atrolineatus when the legume was intercropped with millet compared to when it was the only crop, which these authors attributed to microclimatic factors that favoured the pest.

In some DMC systems, particularly in semi-arid conditions, surface plant residues play an important role in conserving soil water by reducing soil evaporation (Scopel et al. 2004). The water conservation effect of surface residues can therefore both potentially reduce the risk of drought stress, hence contributing to physiological resistance to diseases such as rice blast (see "Section 9.1"), and limit pathogen development via reduced relative humidity above the surface of the soil due to lower evaporation.

In agroforestry systems, PSD can also lead to changes in the plantation microclimate. The intensity of attacks by pests and diseases in these systems varies with the pest and its ecological requirements (Schroth et al. 2000). In coffee (Coffea arabica), shade has been reported to favour Mycena citricolor in Costa Rica (Avelino et al. 2007) (Figs. 15 and 16) but to hamper Colletotrichum kahawae in Cameroon (Mouen Bedimo et al. 2008) due to changes in microclimate.

In a low-elevation dry coffee zone in Central America, Staver et al. (2001) reported that $35 \%$ to $65 \%$ shade reduced Cercospora coffeicola (the pathogen causing brown eye spot disease) and mealybug Planococcus citri while simultaneously increasing the effectiveness of microbial and parasitic organisms without increasing the levels of Hemileia vastatrix (the pathogen causing coffee leaf rust) or reducing yields.

Some antagonistic effects have also been found in cocoa agroforestry systems. For instance, heavy shading in cocoa agroforests may increase pod rot (Phytophthora megakarya) but at the same time may reduce insect (Sahlbergella singularis) attacks and impacts (Bigger 1981). Similarly, 
Fig. 15 Coffee-based

agroforestry system with a dense

shade of eucalyptus and

erythrine at free growth in Costa

Rica (C) J. Avelino, Cirad)

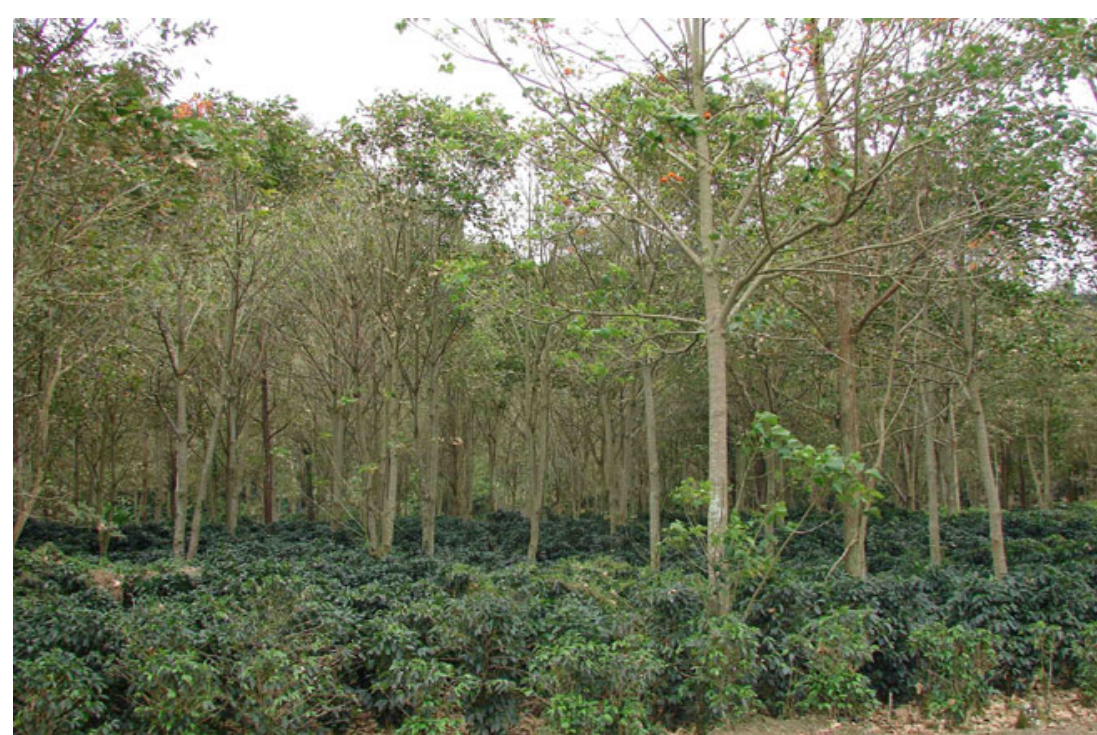

while Phytophthora pod rot is increased by intermediate levels of shade (Beer et al. 1998), stem canker caused by the same fungus is increased in fields exposed to full sunlight due to water stress.

The effects of PSD-induced changes in microclimate are even more complicated to foresee since some may facilitate a particular process in the life cycle of a pest or parasite while hampering the same process in another pest or parasite or another process in the same pest or parasite (Avelino et al. 2004). The overall result of such antagonistic effects on pests and diseases development is consequently not always clear.

PSD-induced changes in microclimate may also indirectly affect pests and diseases via top-down effects. For instance, the humid conditions in agroforestry systems may favour the development of diseases in insect pests. Coupled with the absence of direct sun, the effectiveness of entomopathogenic fungi may be increased by humidity (Jaques 1983). In experiments on the effect of sunlight on the field persistence of Nomuraea rileyi, Fargues et al. (1988) found that the halflife and viability of the spores of this fungus were considerably increased in the shade.

The presence of different shade strata favours generalist predators like spiders and ants (Perfecto et al. 1996), which are natural enemies of mirid bugs (Way and Khoo 1991). On the other hand, Phytophthora is frequently vectored by ants (Evans 1973). The influence of shading and of the shade species on the distribution of ants was studied in cocoa plantations in Ghana (Bigger 1981) and Malaysia (Way and Khoo 1991) and in coffee plantations in Costa Rica (Perfecto and Vandermeer 1996). Detailed studies by Perfecto and Vandermeer (1996), focusing on a key mutualism between an ant (Azteca instabilis) and a scale insect (Coccus viridis) in a coffee agroforestry system in Costa Rica, were described in the previous section ("Section 11") since the ability of $A$. instabilis to establish its nests in shade trees is more closely linked to the architectural characteristics of the trees than to the effects of microclimate. Similarly, Van Mele and Cuc (2007) recommended planting tree or shrub species with large flexible leaves or smaller abundant leaves in the vicinity of citrus or mango orchards in order to help weaver ants Oecophylla spp. (major fruit fly control agents) set up nests and hence to encourage their presence all year round.

While microclimate can directly affect the pest and its natural enemies, it also has effects via the physiology of the host. Under shade, flower initiation and the yield of coffee trees $(C$. arabica) are lower than under full sun. Yield can actually be very low under excessive shade. On the other

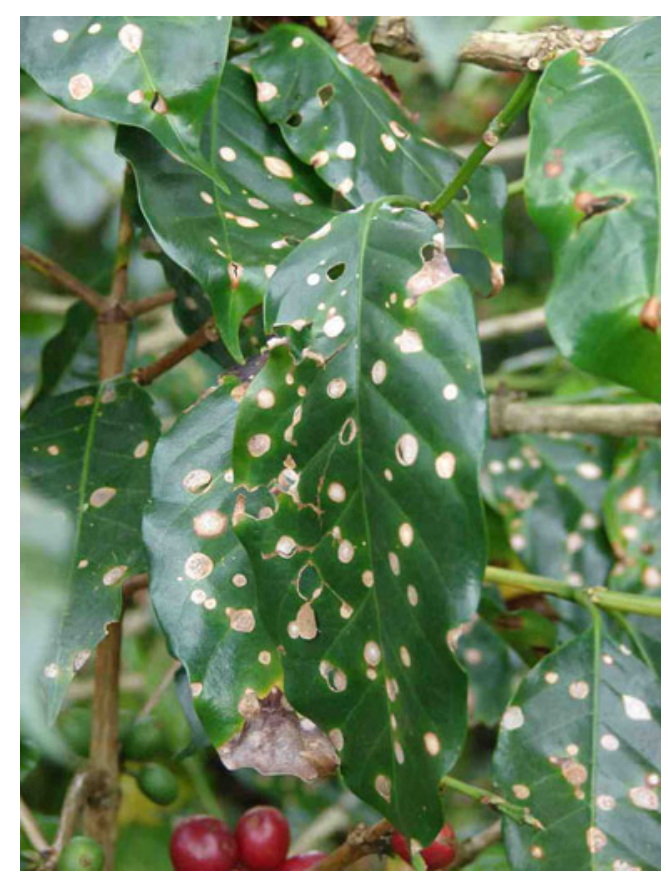

Fig. 16 M. citricolor lesions on coffee leaves (C J. Avelino, Cirad) 
hand, coffee rust $(H$. vastatrix $)$ epidemics are more intense when coffee yield is high (Avelino et al. 2004; 2006). As a result of the effects of shade on yield, a high percentage of shade has been reported to negatively affect the development of coffee rust (Avelino et al. 2004; 2006).

The plant barriers discussed in "Section 13", which stresses the effects of obstacles on the movement of pests and diseases, can also change the microclimate by acting as windbreaks. Wind can cause mechanical wounds that facilitate infection by weakness pathogens (Schroth et al. 2000). Wind can also change the temperature of the cultivated plot, increasing it if wind is hot and decreasing it if wind is cold.

\section{Physical barrier effects on crop pests and diseases}

These effects are distinct from the effects of disrupting the spatial cycle described in "Section 3.2", which refers mainly to host/non-host status rather than to mere physical disruption of PSD plants. Barrier effects can occur both at the plot and at the landscape levels.

13.1 Barrier effects against pests and pathogens at the field level

For instance, in agroforestry systems, hedges, boundary plantations and windbreaks affect the colonization and dispersal of both herbivorous and predatory parasitic insects. Both horizontal and vertical movements of insects are affected by tall or dense woody plantations (Pasek 1988).

The tall woody plants in agroforestry or in hedgerow trees systems can act as a physical barrier to the movement of insects to, from and within the system, especially if these insects are passively transported by wind (Schroth et al. 2000) or if they have a very limited flight height. This situation is advantageous if the entry of the insect pests is blocked or if outward movement of the natural enemies of the pests is hindered.

In agroecosystems based on annual crops, several tall non-host plants, primarily Gramineae, have been tested as barrier crops or intercrops to reduce whitefly colonization and virus transmission among main crops. Smith and McSorley (2000) reported that a sorghum, S. bicolor, barrier reduced B. tabaci densities and transmission of the virus on tomato, $L$. esculentum

A pearl millet, Pennisetum glaucum, barrier reduced whitefly virus transmission on cowpea, $V$. unguiculata (Sharma and Verma 1984), and on soybean, G. max (Rataul et al. 1989). Results obtained on bean/corn (Zea mays) intercrops were mixed (Smith and McSorley 2000).

The only successful case of control of a virus carried by a homopteran pest (aphids) by trap cropping reported by
Shelton and Badenes-Perez (2006) was possible because of the cultivation of a perimeter trap crop acting as a barrier crop (intercepting aphids moving passively into the field). Barrier crops can thus be an effective crop management strategy for the control of viruses that are non-persistently transmitted by aphid-borne viruses under particular circumstances (Fereres 2000; Hooks and Fereres 2006).

Air-borne pathogens can be affected by physical barriers at the field scale despite their usually high ability to produce large quantities of propagules which are then disseminated over great distances by the wind. For instance, reductions in conidial density of $A$. solani on tomato due to intercropping with marigold (T. erecta: see "Section 3.2" above) or pigweed (Amaranthus hypochondriacus) were partly attributed to the effect of a physical barrier on the dissemination of conidia (Gomez-Rodriguez et al. 2003).

A physical barrier is also effective against splashborne propagules, as in the case of Septoria tritici. The vertical dispersal of pycnidiospores from basal lesions on wheat was partially impeded by a clover understorey, which acted as a sieve (Bannon and Cooke 1998).

Ristaino et al. (1997) found that planting a pepper crop in stubble left over from a no-till wheat cover crop significantly reduced the dispersal of Phytophthora capsici inoculum and the subsequent occurrence Phytophthora blight disease, which was mainly attributed to a simple reduction in splash dispersal of surface inoculum to aboveground parts of the plants.

Similarly, a sudangrass (S. bicolor var. sudanensis cv. Trudan 8) cover crop was shown to reduce the splash dispersal of conidia of Colletotrichum acutatum Simmonds, the causal agent of anthracnose of strawberry (Ntahimpera et al. 1998).

Mills et al. (2002) found that a decrease in tomato foliar diseases (early blight caused by $A$. solani, and Septoria leaf spot, caused by Septoria lycopersici) in a dead mulch of hairy vetch (Vicia villosa) was associated with reduced splash dispersal.

Effects of physical barriers have also been proposed for the soil-borne bacteria Pseudomonas (=Ralstonia) solanacearum, the causal agent of bacterial wilt of tomato. Intercropping tomato with cowpea within the row reduced the intensity of a bacterial wilt attack (Michel et al. 1997). These authors suggested that the physical barrier created by the cowpea roots delayed the transmission of the pathogen from infected to healthy tomato roots.

13.2 Barrier effects against pests and pathogens at the landscape level

At the landscape level, increased connectivity may favour dispersal of noxious organisms, which may conflict with strategies aimed at the conservation of desirable species, as 
stressed by Zadoks (1999): "Whereas nature conservation and natural biological control require biotopes (refuges) with maximum connectivity to promote desirable species, pest and disease control wants to minimize connectivity to reduce the spread of noxious species".

The hypothesis that increased connectivity between susceptible plantations increases the spread of pests and diseases was discussed by Perkins and Matlack (2002) in a study on pine forests in southern Mississippi. They demonstrated that modern forests cover a greater proportion of landscape than formerly and consequently that connectivity has increased. According to these authors, the severe attacks of the southern pine beetle (Dendroctonus frontalis) and fusiform rust (Cronartium quercuum), whose dispersal ability is limited to a few hundred metres, resulted from the increased connectivity between susceptible plots. They suggested that $600-900$-m-wide barriers of non-host vegetation could help to control these two bio-aggressors.

The effect of landscape connectivity on the intensity of a disease has been established in the case of sudden oak death, an emerging forest disease caused by Phytophthora ramorum (Condeso and Meentemeyer 2007). Disease severity was positively correlated with the area of host woodland surrounding the infected plot. These authors suggested that this relationship could be explained by a greater amount of inoculum and by the facilitated spread of the disease in large areas of continuous forest. They concluded that forest fragmentation may hinder the development of tree pathogens.

Long-distance aerial dispersal is an important survival strategy for fungal and fungus-like pathogens that cause crop diseases, such as rusts (Uredinales), powdery mildews (Erysiphales) and downy mildews (members of the protist family Peronosporaceae) (Brown and Hovmøller 2002). Consequently, to reduce their spread, it may be necessary to increase crop species richness at larger spatial scales.

Ricci et al. (2009) found that the number of codling moths decreased with an increase in the presence of hedgerows/windbreaks (generally monospecific, composed either of poplar or cypress trees), which offer protection from the prevailing wind. The decrease was mainly attributed to barrier effects and to a lesser extent to indirect effects such as a change in microclimate, reduced efficiency of sexual communication (via pheromones) or increased efficiency of pesticide use, but not to an increase in the impact of the natural enemies of codling moths since there was a significant negative correlation with hedgerow orientation, not with hedgerow length.

13.3 Negative impacts of barrier effects via natural enemy arrestment or facilitation of pest action

Pests' natural enemies are also affected by landscape structure, which may result in counteractive processes
(Schmidt et al. 2004). The abundance and diversity of predators and parasitoids may also be more strongly affected by habitat fragmentation than the abundance and diversity of the herbivorous hosts, even at the scale of a few hundred metres, suggesting that third-trophic-level insects disperse or colonize less efficiently than second- trophiclevel insects (Elzinga et al. 2007; Tscharntke and Brandl 2004; Van Nouhuys and Hanski 2002).

Insects such as aphids, thrips, flies and small beetles with limited flying ability are carried far afield by wind (Singh Rathore 1995), although recent evidence showed that such flight behaviours are not always "passive" (Reynolds and Reynolds 2009). However, this is the case of whitefly adults, which move passively with wind currents like "aerial plankton" (Byrne and Bellows 1991).

Once in the air, these insects cannot land directly on their host-plant plots because of the high speed of the wind carrying them. They use tall trees as obstructions to settle on and later move to the crop fields. Thus, the trees in an agroforestry system, or hedges in annual cropping systems, may facilitate colonization of insect pests by providing a platform from which they subsequently launch themselves to infest the crops (Epila 1988).

\section{Conclusions and directions for future research on PSD-induced effects on pests and diseases}

\subsection{Main lessons drawn from the literature review}

In this review, we have reported on several PSD-induced effects on crop pests and diseases that are summarized in Fig. 1. We have emphasized those that appear to be of generic value and avoided elaborating on effects that might be just anecdotic or are still awaiting confirmation as to whether they are appropriate for PSD or not. The general principles underlying these effects and/or pathways are summarized in Tables 1,2 and 3 according to the level at which the type of PSD and its effects occur.

Our review of the literature confirmed that it is not necessarily true that vegetational diversification reduces the incidence of pests and diseases.

Above and beyond the ability of some pests and pathogens to use a wide range of plants as alternative hosts/reservoirs (which is the main limitation to the suppressive role of the PSD strategy), all the other identified pathways of PSD-based pest or disease control do have certain limitations.

\subsection{PSD effects at the soil and field levels}

In particular, the ability of some pathogens and pests to survive and breed on different hosts and habitats at different 
Table 1 General rules/principles according to which the use of PSD at the soil/plant to field levels (via crop rotation, intercropping, DMC and agroforestry) results in improved control of crop pests and diseases in agroecosystems and the main exceptions to these rules (with examples)

\begin{tabular}{|c|c|c|}
\hline $\begin{array}{l}\text { Regulatory mechanism } \\
\text { of the pest or disease }\end{array}$ & General principles (and typical examples) & $\begin{array}{l}\text { Main drawbacks or limitations } \\
\text { (and typical counter-examples) }\end{array}$ \\
\hline $\begin{array}{l}\text { Disruption of temporal } \\
\text { cycle }\end{array}$ & $\begin{array}{l}\text { Crop rotation with non-host crop reduces the soil-borne } \\
\text { pathogen inoculum or the pest carry-over population } \\
\text { (e.g. LaMondia et al. 2002) }\end{array}$ & $\begin{array}{l}\text { This is not suitable for pathogens and pests with a broad } \\
\text { host range, high dispersal ability or long-lived forms } \\
\text { in the soil (e.g. Weinhold et al. 1964) }\end{array}$ \\
\hline Allelopathy & $\begin{array}{l}\text { Antibiotic components produced/released in the soil by } \\
\text { some plants directly affect feeding/infection/ } \\
\text { attachment ability of pests or pathogens on crop host } \\
\text { plants (e.g. Khan et al. 2002) }\end{array}$ & $\begin{array}{l}\text { Depending on the cultivar used, the opposite effect may } \\
\text { be observed (e.g. Smith et al. 2004) }\end{array}$ \\
\hline $\begin{array}{l}\text { Soil suppressiveness via } \\
\text { enhanced diversity/ } \\
\text { activity of soil biota }\end{array}$ & $\begin{array}{l}\text { Organic material derived from PSD plants increases the } \\
\text { general level of microbial activity, and the more } \\
\text { microbes there are in the soil the greater the chances } \\
\text { that some of them will be antagonistic to pathogens } \\
\text { (e.g. Insunza et al. 2002) }\end{array}$ & $\begin{array}{l}\text { The TAD phenomenon on wheat provides a counter- } \\
\text { example of this principle (e.g. Weller et al. 2002) }\end{array}$ \\
\hline $\begin{array}{l}\text { Physiological resistance } \\
\text { via improved crop } \\
\text { nutrition }\end{array}$ & $\begin{array}{l}\text { Varied crop rotations or intercrops contribute to better } \\
\text { crop nutrition thanks to minerals derived from the } \\
\text { decomposition of organic matter, which has a positive } \\
\text { effect on crop resistance to pests and diseases } \\
\text { (e.g. Krupinsky et al. 2002) }\end{array}$ & $\begin{array}{l}\text { Good host nitrogen nutrition favours the development of } \\
\text { biotrophic fungi (e.g. MacLean et al. 1992) }\end{array}$ \\
\hline
\end{tabular}

PSD Plant Species Diversity; DMC Direct Seeding, Mulch Based Cropping; TAD Take-all decline

times in their life cycle makes them very difficult to control. This applies to both intercropped plants and to some plants used in a rotational strategy.

The "plant exposure/visibility" and "resource concentration" theories may explain why polycultures generally support lower specialist or oligophagous herbivore loads (and when applicable, reduced incidence of insect-transmitted viral diseases) than do monocultures. In addition to pest specificity, dispersal ability and the scale of PSD deployment are critical for predicting how PSD will affect pest communities.

The principle of disrupting the spatial cycle is at play in non-insect-transmitted host-specific diseases whose severity decreases with an increase in species richness via a decrease in host density. However, when the economic value of the intercropped or undersown plant is lower than that of the main crop (especially weed covers), the farmer only gains when the increase in crop quality due to the reduction in the incidence of pests or diseases compensates for the reduction in yield due to competition for water and nutrients.

The trap cropping mechanism is to some extent the reverse of the disruptive crop mechanism in that pests are attracted to - rather than repelled by — associated plants and are less likely to wander into the main crop. The fact that, among the long list of plants that show potential for pest

Table 2 General rules/principles according to which the use of PSD in the field and immediate surroundings (via intercropping, DMC and perimeter cropping) results in improved control of crop pests and diseases in agroecosystems and the main exceptions to these rules (with examples)

\begin{tabular}{|c|c|c|}
\hline $\begin{array}{l}\text { Regulatory } \\
\text { mechanism of the } \\
\text { pest or disease }\end{array}$ & General principles (and typical examples) & $\begin{array}{l}\text { Main drawbacks or limitations } \\
\text { (and typical counter-examples) }\end{array}$ \\
\hline $\begin{array}{l}\text { Disruption of the } \\
\text { spatial cycle }\end{array}$ & $\begin{array}{l}\text { Separation of hosts and non-hosts limits the spread of } \\
\text { pathogens and pests (e.g. Mitchell et al. 2002) }\end{array}$ & $\begin{array}{l}\text { This is not suitable for pests/pathogens with a } \\
\text { broad host range and/or high dispersal ability (e.g. } \\
\text { Banks 1998) }\end{array}$ \\
\hline Resource dilution & $\begin{array}{l}\text { In polycultures, crop plants are less visible/exposed than in } \\
\text { monocultures and therefore generally support lower specialist or } \\
\text { oligophagous herbivore loads (e.g. Finch and Kienegger 1997) }\end{array}$ & $\begin{array}{l}\text { This is limited by competition by non-productive } \\
\text { plants for resources with the main crop } \\
\text { (e.g. Schellhorn and Sork 1997) }\end{array}$ \\
\hline Deterrent diversion & $\begin{array}{l}\text { Repellent semiochemicals produced by a plant that is intercropped } \\
\text { or undersown result in bottom-up effects against pests of the } \\
\text { main crop (e.g. Kimani et al. 2000) }\end{array}$ & $\begin{array}{l}\text { This process may also attract non-target pests to } \\
\text { the crop (e.g. Latheef and Ortiz 1983) }\end{array}$ \\
\hline Stimulant diversion & $\begin{array}{l}\text { Pests are attracted to associated plants and are less likely to wander } \\
\text { into the main crop; natural enemies are attracted on the crop and } \\
\text { control pests (e.g. Van den Berg 2006) }\end{array}$ & $\begin{array}{l}\text { Trap plants may turn from "sinks" into "sources" } \\
\text { of pests (e.g. Hilje et al. 2001) }\end{array}$ \\
\hline
\end{tabular}

PSD Plant Species Diversity; DMC Direct Seeding, Mulch Based Cropping 
Table 3 General rules/principles according to which the use of PSD at the field and landscape levels (via intercropping, DMC, perimeter cropping, non-crop field margins and strips, agroforestry and landscape fragmentation) results in improved control of crop pests and diseases in agroecosystems and the main exceptions to these rules (with examples)

\begin{tabular}{|c|c|c|}
\hline $\begin{array}{l}\text { Regulatory } \\
\text { mechanism of the } \\
\text { pest or disease }\end{array}$ & General principles (and typical examples) & $\begin{array}{l}\text { Main drawbacks or limitations } \\
\text { (and typical counter-examples) }\end{array}$ \\
\hline
\end{tabular}

\begin{tabular}{ll}
\hline $\begin{array}{l}\text { Provision of } \\
\text { alternative food to }\end{array}$ & $\begin{array}{l}\text { PSD vegetation provides pollen and nectar as critical food } \\
\text { aerial natural }\end{array}$ \\
enemies & $\begin{array}{l}\text { hosts/preys that sustain/increase parasitoid/predator } \\
\text { populations before the arrival of the target crop pest } \\
\text { (e.g. Tylianakis et al. 2004) }\end{array}$
\end{tabular}

Provision of refugia/ shelter for aerial natural enemies

\section{Microclimate alteration}

Physical obstruction
PSD architectural traits protect natural enemies from top predators or provide nesting/oviposition substrates in ways that hamper crop pests or diseases or favour their natural enemies (e.g. Jones and Sieving 2006)

PSD may alter microclimate in ways that inhibit pest development/pathogen growth and/or encourage development/growth of natural enemies (e.g. Staver et al. 2001)

At the field level, mulches or intercrops reduce disease propagation notably via reduced splashing; at the landscape level, fragmentation/non-connectivity blocks the movement of pests and spread of diseases (e.g. Sharma and Verma 1984)
PSD vegetation may also increase the fitness of herbivore pests as via provision of floral resources

(e.g. Lavandero et al. 2006)

Some predator or parasitoid species may choose either pest honeydew or plant resources (pollen or nectar) over prey (e.g. Robinson et al. 2008)

"Positive" prey-prey interaction, with diversion of target pest predation by a natural enemy due to the availability of alternate prey (e.g. Halaj and Wise 2002)

This may result in conflicting effects, e.g., of ants on pests, diseases and natural enemies

(e.g. Perfecto and Vandermeer 2008)

PSD may alter microclimate in ways that encourage the development of pests and pathogens and/or inhibit the development/growth of natural enemies

(e.g. Schroth et al. 2000)

Fragmentation at both field and landscape scales may hinder the movement of natural enemies (e.g. Schmidt et al. 2004)

PSD Plant Species Diversity; DMC Direct Seeding, Mulch Based Cropping

management via trap cropping, only a few attempts have been successful at a commercial level is probably a sign that this strategy is tricky to implement.

Indeed conventional trap plants with no dead-end properties have to be managed specifically to prevent them from turning from "sinks" for pests into "sources" for the same pests while, on the other hand, dead-end trap plants might end up selecting pest populations that will counter suicidal egglaying behaviour by pests. Also, trap crops (as intercrops or border plants) that are not intended for harvest compete with the main crop for water and nutrients. Nevertheless, as is true of some repellent intercrops, top-down effects may assist the pest-suppressing capacity of certain trap plants.

Thus, some plants used as intercrops may release volatiles that mediate the behaviour of both pests and parasitoids. These semiochemicals are produced during damage to plants by herbivorous insects, e.g. by cereals in the case of a high level of colonization by stem borers, and in the case of the successful use of push-pull principles for the management of cereal stem borers in eastern and southern Africa, these compounds likely act both as repellents to ovipositing moths and as foraging cues for parasitoids.

Among the pests and diseases discussed in this review, the "trap cropping/suicidal germination induction" below-ground allelopathic regulation pathways mainly concern Striga spp. and some nematodes. In both cases, varietal (genetic) diversity within "trap" crop species should be taken into account. Obviously, this aspect is crucial in the case of Brassicaceous green manures for the control of parasitic nematodes since, depending on the cultivar used, the outcome may be either pest suppression or pest enhancement.

Direct biocidal or biostatic effects during plant growth mainly concern nematodes. However, the biocidal effect on various fungi and bacteria of several compounds released by different plant species in a range of families has also been identified along with compounds that are toxic or are feeding deterrents for some insects.

Although service plants with bio-fumigating properties may have a function in soil improvement as green manures, the same reservations as for non-harvestable repellent or trap plants may apply in the case of biofumigation. Nonetheless, the ban on methyl bromide is a major incentive for the use of this technique. Still, despite promising results, much remain to be done in terms of process optimization. It is important to be aware of the potential increase in root-knot nematodes caused by some Brassica crops during their growing stage despite biofumigation action during decomposition (although conservative measures can be taken in this case) and of the potentially adverse effects of certain biofumigants involving broad-spectrum molecules on bene- 
ficial soil organisms or natural enemies of targeted pests (although evidence for such adverse effects is rare).

The addition of organic material to the soil, particularly material derived from selected PSD, may increase the general level of microbial activity more than directly inoculating the soil with beneficial microorganisms. However, the phenomenon of soil resistance to the take-all disease of wheat provides a counter-example to the principle that the more microbes there are in the soil the greater the chances that some of them will be antagonistic to pathogens. Still the positive effect generally holds true and may even apply to soil macrofauna, including some pest species.

Also, some plant species can stimulate antagonists in the rhizosphere, which may lead to an increase in the abundance of chitinolytic organisms and modifications in nematode and fungi communities. Phenolic compounds (tannins) contained in organic matter with a high $\mathrm{C} / \mathrm{N}$ ratio derived from some plant species also have a suppressive effect on fungi and nematodes.

A variety of crop rotations or intercrops also contribute to better and more balanced soil fertility and hence to better crop nutrition thanks to minerals derived from the decomposition of organic matter, which has a positive effect on crop resistance to pests and diseases, at least as far as necrotrophic pathogens are concerned. Better water nutrition via reduced evaporation thanks to mulching may also help crops overcome attacks by pests or pathogens. On the other hand, good host nitrogen nutrition favours the development of biotrophic fungi, and water stress may trigger plant resistance to some pests.

Increased diversity of cropping systems generally results in more balanced soil fertility thus contributing to lower pest and disease incidence via trophobiosis. However, an excessive amount of $\mathrm{N}$-rich biomass may result in increased incidence of biotrophic pathogens and associated diseases. On the other hand, systems based on organic matter-derived nutrients, although released in a balanced and regular manner, are predominantly $\mathrm{N}$-limited so that mineral $\mathrm{N}$ should be applied when the crop demand is greatest.

Some other minerals present in certain PSD plants may also confer specific resistance to particular pests or diseases. Manganese is one such nutrient which is associated with increased resistance to a number of crop diseases and whose availability is affected by crop rotation. However, the same is generally not true of silicon: it remains to be established whether $\mathrm{Si}$ availability to plants and subsequent Si-based resistance to pests and diseases can be induced by PSD or whether PSD via appropriate rotations may just slow down the depletion of $\mathrm{Si}$ in soils.

\subsection{PSD effects at the field and landscape levels}

Habitats made of perennial and annual vegetation located outside cropped fields, as providers of alternative hosts or supplementary floral food for crop pests, may serve as sources of infestation to cultivated fields. However, even more importantly, they may play a role as a source of pollen and nectar for adults of pest parasitoids. Making generalizations about the relationship between landscape composition and parasitoid biodiversity though is even more complicated by the fact that some predator or parasitoid species may prefer either honeydew and plant resources to pollen or nectar to a diet of prey.

Wild perennial and annual vegetation can act as "banks" for parasitoids and predators of crop pests by increasing the population of these parasitoids/predators on the alternative prey they shelter before the arrival of the target pest on the neighbouring crop. However, such "negative prey-prey interactions", which result in improved control of the target pest, is not the general rule. There are also several reported instances of "positive prey-prey interaction", when an alternative prey diverts predation exerted by a natural enemy away from the target pest, thus negatively affecting pest biological control.

In addition to trophic services such as provision of alternate prey or supplementary floral food, shelter habitats provide beneficial arthropods with suitable conditions for several biological activities and a refuge from disturbances caused by farming practices and aerial predators. On the other hand, the action of insectivore birds whose overall predation is mainly detrimental to herbivorous insects may be encouraged by the addition of some PSD intercrops as perching substrates. Also, some agroforestry shade trees can provide nesting substrates for ants, thus creating complex mutualism/antagonistic chains that can affect crop pests and diseases in several different ways.

Some types of crop diversification can alter microclimate in ways that either encourage or inhibit the growth of pathogens or the development of pests, depending on the characteristics of the pathogen, the plants and the local environment. Although microclimate can directly affect the pest and its natural enemies, it may also have effects via the physiology of the host.

PSD-induced barrier effects are involved both at the plot and at the landscape levels (not to mention the fact that some mulches function as barriers to weed or parasitic plant emergence) as shown in the variety of instances reported in agroforestry or in agroecosystems based on annual crops. At the landscape level, increased connectivity associated with some forms of PSD may favour the dispersal of noxious organisms, which might conflict with some strategies aimed at the conservation of desirable species. Pests and their multiple enemies are simultaneously affected by landscape structure, leading to opposing processes.

\subsection{Directions for future research}

Several successful examples of the regulating effects of PSD on pests and diseases derive from "pathosystems" drawn 
from complex systems such as DMC systems (Ratnadass et al. 2006b), food crop- or vegetable crop-based "push-pull" systems (Cook et al. 2007) and agroforestry systems. This is the case of pests and diseases in cocoa- and coffee-based agroforestry systems (Schroth et al. 2000; Staver et al. 2001) and for Striga in DMC systems (Husson et al. 2008) or for stem borers in push-pull systems (Khan et al. 1997a).

The more synergistic effects there are (particularly when both bottom-up and top-down effects are involved as in the above-mentioned complex systems), the more sustainable the system is likely to be in mobilizing ecologically based pest- and disease-regulating mechanisms.

This would also limit (or delay) the capacity of the pest and pathogen to overcome individual PSD-based regulation processes, as happens with other methods of control. Actually, with the aim of postponing this process even longer, PSD-based pest and disease regulatory methods can also be combined with other environmentally friendly techniques such as some forms of biological control.

Although a review of the literature can obviously help select useful forms of pathosystem/PSD typology-based indicators, a new approach is needed for the design and management of an integrated ecosystem (Hill et al. 1999). Any recommendation on how to reduce damage caused by pests and diseases should be accompanied by an indication of the predictability and reliability of the suggested PSDbased technique; unfortunately, the results of decades of field studies in agroecology do not bode well for the establishment of a generalized, reliable protocol for the use of diversity in crop fields (Banks and Ekbom 1999).

As the numerous combinations of species, environments and practices are beyond the scope of traditional factorial experimental approaches, a systems approach and dynamic modelling tools are required to improve our understanding of the processes involved and to evaluate adequate management schemes in dynamic systems with heterogeneous structures (Malézieux et al. 2009).

Modelling should be used as a tool for incepting and developing PSD-based cropping systems that are resilient to pests and diseases, particularly to validate hypotheses (general qualitative mechanistic explanations for empirical results) or to quantify the importance of manipulable vegetation characteristics of agroecosystems for the control of pests and diseases, particularly to optimize systems that can have antagonistic effects. Such an approach is currently being applied in Cirad's Omega3 project (Ratnadass et al. 2010).

When complex situations result in opposing effects (either in relation to agronomic constraints or conflicting effects on components of the pest/disease complex), one may also consider replacing 'real' PSD effects by mimics of PSD regulatory effects on pests and diseases to tackle a particular pest or disease that cannot be controlled by PSD.
In this respect, even though it mimics naturally occurring ecological processes, the use of genetically engineered trap plants is still under debate, depending on whether one stresses its negative effects on plant biodiversity in ecosystems via other pathways (Altieri et al. 2004) or on the potential benefits for microbial biodiversity and non-target arthropod biodiversity of the use of respectively herbicide-tolerant GM crops (via enhanced no-till cultivation) and insecticideresistant crops (via reduced insecticide use) (Ammann 2005).

Acknowledgements We thank the two anonymous referees and the Editor-in-Chief for their helpful comments and Daphne Goodfellow for English revision. This publication was financially supported by Cirad/DGDRS (Omega3 project).

Open Access This article is distributed under the terms of the Creative Commons Attribution Noncommercial License which permits any noncommercial use, distribution, and reproduction in any medium, provided the original author(s) and source are credited.

\section{References}

A'Brook J (1968) The effects of plant spacing on the number of aphids trapped over the groundnut crop. Ann Appl Biol 61:289-294

Almeida RPP, Blua MJ, Lopes JRS, Purcell AH (2005) Vector transmission of Xylella fastidiosa: applying fundamental knowledge to generate disease management strategies. Ann Entomol Soc 98:775-786

Altieri MA (1999) The ecological role of biodiversity in agroecosystems. Agric Ecosyst Environ 74:19-31

Altieri MA, Gurr GM, Wratten SD (2004) Genetic engineering and ecological engineering: a clash of paradigms or scope for synergy? In: Gurr GM, Wratten SD, Altieri MA (eds) Ecological engineering for pest management: advances in habitat manipulation for arthropods. CSIRO publishing, Collingwood, Australia, pp 13-31

Ammann K (2005) Effects of biotechnology on biodiversity: herbicide-tolerant and insect-resistant GM crops. Trends Biotechnol 23(8):388-394. doi:10.1016/j.ytibtech.2005.06.008

Andow DA (1991) Vegetational diversity and arthropod population response. Annu Rev Entomol 36:561-586

Andrianaivo AP, Kachelriess S, Kroschel J, Zehrer W (1998) Biologie et gestion du Striga à Madagascar. FOFIFA, DPV, GTZ

Asman K, Ekbom B, Ramert B (2001) Effect of intercropping on oviposition and emigration of the leek moth (Lepidoptera: Acroplepiidae) and the diamondback moth (Lepidoptera: Plutellidae). Environ Entomol 30:288-294

Avelino J, Willocquet L, Savary S (2004) Effects of crop management patterns on coffee rust epidemics. Plant Pathol 53:541-547. doi:10.1111/j.1365-3059.2004.01067.x

Avelino J, Zelaya H, Merlo A, Pineda A, Ordoñez M, Savary S (2006) The intensity of a coffee rust epidemic is dependent on production situations. Ecol Modell 197:431-447. doi:10.1016/j. ecolmodel.2006.03.013

Avelino J, Cabut S, Barboza B, Barquero M, Alfaro R, Esquivel C, Durand J-F, Cilas C (2007) Topography and crop management are key factors for the development of American leaf spot epidemics on coffee in Costa Rica. Phytopathology 97:15321542. doi:10.1094/PHYTO-97-12-1532

Badenes-Perez FR, Shelton AM, Nault BA (2005) Using yellow rocket as a trap crop for diamondback moth (Lepidoptera: Plutellidae). J Econ Entomol 98:884-890 
Baggen LR, Gurr GM (1998) The influence of food on Copidosoma koehleri (Hymenoptera: Encyrtidae), and the use of flowering plants as a habitat management tool to enhance biological control of potato moth, Phthorimaea operculella (Lepidoptera: Gelechiidae). Biol Control 11:9-17

Banks JE (1998) The scale of landscape fragmentation affects herbivore response to vegetation heterogeneity. Oecologia 117:239-246

Banks JE, Ekbom B (1999) Modelling herbivore movement and colonization: pest management potential of intercropping and trap cropping. Agric For Entomol 1:165-170

Bannon FJ, Cooke BM (1998) Studies on dispersal of Septoria tritici pycnidiospores in wheat-clover intercrops. Plant Pathol 47:4956

Barbosa LCA, Barcelos FF, Demuner AJ, Santos MA (1999) Chemical constituents from Mucuna aterrima with activity against Meloidogyne incognita and Heterodera glycines. Nematropica 29:81-88

Beer J, Muschler R, Kass D, Somarriba E (1998) Shade management in coffee and cacao plantations. Agroforest Syst 38:139-164

Bernard EC, Montgomery-Dee ME (1993) Reproduction of plantparasitic nematodes on winter rapeseed (Brassica napus ssp. oleifera). J Nematol 25:863-868

Bianchi FJJA, Booij CJH, Tscharntke T (2006) Sustainable pest regulation in agricultural landscapes: a review on landscape composition, biodiversity and natural pest control. Proc R Soc B 273:1715-1727. doi:10.1098/rspb.2006.3530

Bigger M (1981) Observations on the insect fauna of shaded and unshaded Amelonado cocoa. Bull Entomol Res 71:107-119

Blanchart E, Villenave C, Viallatoux A, Barthès B, Girardin C, Azontonde A, Feller C (2006) Long-term effect of a legume cover crop (Mucuna pruriens var. utilis) on the communities of soil macrofauna and nematofauna, under maize cultivation, in southern Benin. Eur J Soil Biol 42:136-144. doi:10.1016/j. ejsobi.2006.07.018

Blum LEB, Rodriguez-Kabana R (2006) Dried powders of kudzu, velvetbean, and pine bark added to soil increase microbial population and reduce southern blight of soybean. Fitopatol Bras 31:551-556

Boudreau MA, Mundt CC (1997) Ecological approaches to disease control. In: Rechcigl NA, Rechcigl JE (eds) Environmentally safe approaches to crop disease control. CRC, Boca Raton, pp $33-62$

Brévault T, Bikay S, Maldes J-M, Naudin K (2007) Impact of a no-till with mulch soil management strategy on soil macrofauna communities in a cotton cropping system. Soil Tillage Res 97:140-149. doi:10.1016/j.still.2007.09.006

Brown JKM, Hovmøller MS (2002) Aerial dispersal of fungi on the global and continental scales and its consequences for plant diseases. Science 297:537-541

Brown GG, Oliveira LJ (2004) White grubs as agricultural pests and as ecosystem engineers. Abstract for 14th International Colloqium on Soil Zoology and Ecology, Rouen, France

Brunt AA, Crabtree K, Dallwitz MJ, Gibbs AJ, Watson L (1996) Viruses of plants. CAB International, Wallingford

Bush L, Slosser JE, Worrall WD, Horner NV (1991) Potential of wheat cultivar mixtures for greenbug (Homoptera: Aphididae) management. J Econ Entomol 84:1619-1624

Byrne DN, Bellows TS (1991) Whitefly biology. Annu Rev Entomol 36:431-457

Calegari A, Ashburner J (2003) Some experiences with conservation agriculture in Africa. III World Congress on Conservation Agriculture, Nairobi

Castilla NP, Vera Cruz CM, Mew TW (2003) Using rice cultivar mixtures: a sustainable approach for managing diseases and increasing yield. Int Rice Res Notes 28:5-11
Caubel G, Chaubet B (1985) Eclosion et multiplication de Heterodera schachtii Schmidt en présence de colza ou de radis fourragers. Agronomie 5:463-466

Chaboussou F (2004) Healthy crops: a new agricultural revolution. Carpenter, Charnley

Colley MR, Luna JM (2000) Relative attractiveness of potential beneficial insectary plants to aphidophagous hoverflies (Diptera: Syrphidae). Environ Entomol 29:1054-1059

Collier R, Finch S, Davies G (2001) Pest insect control in organicallyproduced crops of field vegetables. Proceedings: 53rd International Symposium on Crop Protection, University of Ghent, Belgium, pp 259-267

Condeso TE, Meentemeyer KR (2007) Effects of landscape heterogeneity on the emerging forest disease sudden oak death. J Ecol 95:364-375. doi:10.1111/j.1365-2745.2006.01206.x

Cook RJ (1981) The influence of rotation crops on take-all decline phenomenon. Phytopathology 71:189-192

Cook SM, Khan ZR, Pickett JA (2007) The use of push-pull strategies in integrated pest management. Annu Rev Entomol 52:375-400. doi:10.1146/annurev.ento.52.110405.091407

Cox CM, Garrett KA, Bowden RL, Fritz AK, Dendy SP, Heer WF (2004) Cultivar mixtures for the simultaneous management of multiple diseases: tan spot and leaf rust of wheat. Phytopathology 94:961-969

Crombie WML, Crombie L (1986) Distribution of avenocins A-1, A-2, B-1 and B-2 in oats roots: their fungicidal activity towards 'take-all' fungus. Phytochemistry 25:2069-2073

Datnoff LE, Deren CW, Snyder GH (1997) Silicon fertilization for disease management of rice in Florida. Crop Prot 16:525-531

Davet P (1996) Vie microbienne du sol et production végétale. INRA, Paris

Dawson T, Fry R (1998) Agriculture in nature's image. Trends Ecol Evol 13:50-51

Deguine J-P, Ferron P, Russell D (2008) Protection des cultures: de l'agrochimie à l'agroécologie. Ed. Quae, Versailles

Dordas C (2008) Role of nutrients in controlling plant diseases in sustainable agriculture. A review. Agron Sustainable Dev 28:3346. doi:10.1051/agro:2007051

Dover KE (1985) The responses of some Lepidoptera to labiate herb and white clover extracts. Entomol Exp Appl 39:177-182

Dover KE, McSorley R, Wang K-H (2003) Marigolds as cover crops. In: IFAS (ed) http://agroecology.ifas.ufl.edu/marigoldsbackground.htm

Elzinga JA, van Nouhuys S, van Leeuwen DJ, Biere A (2007) Distribution and colonisation ability of three parasitoids and their herbivorous host in a fragmented landscape. Basic Appl Ecol 8:75-88. doi:10.1016/j.baae.2006.04.003

England S, Evans EW (1997) Effects of pea aphid (Homoptera: Aphididae) honeydew on longevity and fecundity of the alfalfa weevil (Coleoptera: Curculionidae) parasitoid Bathyplectes curculionis (Hymenoptera: Ichneumonidae). Environ Entomol 26:1437-1441

Epila JSO (1988) Wind, crop pests and agroforest design. Agric Syst 26:99-110

Evans HC (1973) Invertebrate vectors of Phytophtora palmivora, causing black pod disease of cocoa in Ghana. Ann Appl Biol 73:331-345

Evans HC, Holmes KA, Reid AP (2003) Phylogeny of the frosty pod rot pathogen of cocoa. Plant Pathol 52:476-485

Fargues J, Rougier M, Goujet R, Itier B (1988) The effect of sunlight on the field persistence of conidiospores of the entomopathogenic hyphomycete, Nomuraea rileyi, on the surface of vegetables. Entomophaga 33:357-370

Feeny P (1976) Plant apparency and chemical defense. In: Wallace JW, Nansel RL (eds) Biological interactions between plants and insects. Recent advances in phytochemistry, 10. Plenum, New York 
Fereres A (2000) Barrier crops as a cultural control measure of nonpersistently transmitted aphid-borne viruses. Virus Res 71:221-231

Ferron P, Deguine J-P (2005) Vers une conception agroécologique de la protection des cultures. In: Regnault-Roger C (ed) Enjeux phytosanitaires pour l'agriculture et l'environnement. Lavoisier, Paris, pp 347-366

Finch S, Collier RH (2000) Host-plant selection by insects-a theory based on 'appropriate/inappropriate landings' by pest insects of cruciferous plants. Entomol Exp Appl 96:91-102

Finch S, Kienegger M (1997) A behavioural study to help clarify how undersowing with clover affects host plant selection by pest insects of brassica crops. Entomol Exp Appl 84:165-172

Finckh MR, Gacek ES, Goyeau H, Lannou C, Merz U, Mundt CC, Munk L, Nadziak J, Newton AC, Vallavieille-Pope C, Wolfe MS (2000) Cereal variety and species mixtures in practice, with emphasis on disease resistance. Agronomie 20:813-837

Foster SP, Harris MO (1997) Behavioral manipulation methods for insect pest-management. Annu Rev Entomol 42:123-146

Gomez-Rodriguez O, Zavaleta-Mejia E, Gonzalez-Hernandez VA, Livera-Munoz M, Cardenas-Soriano E (2003) Allelopathy and microclimatic modification of intercropping with marigold on tomato early blight disease development. Field Crops Res 83:27-34

Gommers FJ (1981) Biochemical interactions between nematodes and plants and their relevance to control. Helminthol Abstr 50:9-24

Graham DR, Webb MJ (1991) Micronutrients and disease resistance and tolerance in plants. In: Mortvedt JJ, Cox FR, Shuman LM, Welch RM (eds) Micronutrients in agriculture, 2nd edn. Soil Science Society of America, pp 329-370

Greco N, Elia F, Brandonisio A (1986) Control of Heterodera carotae, Ditylenchus dipsaci, and Meloidogyne javanica with fumigant and nonfumigant nematicides. J Nematol 18:359-364

Griffiths GJK, Holland JM, Bailey A, Thomas MB (2008) Efficacy and economics of shelter habitats for conservation biological control. Biol Control 45:200-209. doi:10.1016/j.biocontrol.2007.09.002

Grundy PR, Sequeira RV, Short KS (2004) Evaluating legume species as alternative trap crops to chickpea for management of Helicoverpa spp. (Lepidoptera: Noctuidae) in central Queensland cotton cropping systems. Bull Entomol Res 94:481-486. doi:10.1079/BER2004327

Halaj J, Wise DH (2002) Impact of a detrital subsidy on trophic cascades in a terrestrial grazing food web. Ecology 83:31413151

Halaj J, Cady AB, Uetz GW (2000) Modular habitat refugia enhance generalist predators and lower plant damage in soybeans. Environ Entomol 29:383-393

Hauggaard-Nielsen H, Jensen E (2005) Facilitative root interactions in intercrops. Plant Soil 274:237-250. doi:10.1007/s11104-0041305-1

Helenius J (1998) Enhancement of predation through within-field diversification. In: Pickett E, Bugg RL (eds) Enhancing biological control. University of California Press, Berkeley, CA, USA, pp 121160

Hickman JM, Wratten SD (1996) Use of Phacelia tanacetifolia strips to enhance biological control of aphids by hoverfly larvae in cereal fields. J Econ Entomol 89:832-840

Hilje L, Costa HS, Stansly PA (2001) Cultural practices for managing Bemisia tabaci and associated viral diseases. Crop Prot 20:801-812

Hill SB, Vincent C, Chouinard G (1999) Evolving ecosystems approaches to fruit insect pest management. Agric Ecosyst Environ 73:107-110

Hokkanen H (1991) Trap cropping in pest management. Annu Rev Entomol 36:119-138

Hooks CRR, Fereres A (2006) Protecting crops from non-persistently aphid-transmitted viruses: a review on the use of barrier plants as a management tool. Virus Res 120:1-16. doi:10.1016/j. virusres.2006.02.006
Husson O, Michellon R, Charpentier H, Razanamparany C, Moussa N, Naudin K, Razafintsalama H, Rakotoarinivo C, Andrianaivo AP, Rakotondramanana, Seguy (2008) Le contrôle du Striga par les sytèmes SCV (Semis Direct sur Couverture Végétale permanente). Manuel pratique du semis direct à Madagascar, vol 1. GSDM, Madagascar

Insunza V, Alström S, Eriksson KB (2002) Root bacteria from nematicidal plants and their biocontrol potential against trichodorid nematodes in potato. Plant Soil 241:271-278

Jackson W (2002) Natural systems agriculture: a truly radical alternative. Agric Ecosyst Environ 88:111-117

Jahn GC, Almazan LP, Pacia JB (2005) Effect of nitrogen fertilizer on the intrinsic rate of increase of Hysteroneura setariae (Thomas) (Homoptera: Aphididae) on rice (Oryza sativa L.). Environ Entomol 34:938-943

Jaques RP (1983) The potential of pathogens for pest control. Agric Ecosyst Environ 10:101-126

Johnson MTJ, Lajeunesse MJ, Agrawal AA (2006) Additive and interactive effects of plant genotypic diversity on arthropod communities and plant fitness. Ecol Lett 9:24-34. doi:10.1111/ j.1461-0248.2005.00833.x

Jones G, Sieving KE (2006) Intercropping sunflower in organic vegetables to augment bird predators of arthropods. Agric Ecosyst Environ 117:171-177. doi:10.1016/j.agee.2006.03.026

Kanwar RS, Bhatti DS (1994) Crucifers and garlic (Allium sativum) as rotational crops to manage root-knot nematode (Meloidogyne javanica) in vegetable crops. Indian J Agric Sci 5:339-342

Kaut AHEE, Mason HE, Navabi A, O’Donovan JT, Spaner D (2008) Organic and conventional management of mixtures of wheat and spring cereals. Agron Sustainable Dev 28:363-371. doi:10.1051/ agro:2008017

Kayeke J, Sibuga PK, Msaky JJ, Mbwaga A (2007) Green manure and inorganic fertiliser as management strategies for witchweed and upland rice. Afr Crop Sci J 15:161-171

Khan ZR, Chiliswa P, Ampong-Nyarko K, Smart LE, Polaszek A, Wandera J, Mulaa MA (1997a) Utilisation of wild gramineous plants for management of cereal stemborers in Africa. Insect Sci Appl 17:143-150

Khan ZR, Ampong-Nyarko K, Chiliswa P, Hassanali A, Kimani S, Lwande W, Overholt WA, Pickett JA, Smart LE, Wadhams LJ, Woodcock CM (1997b) Intercropping increases parasitism of pests. Nature 388:631-632

Khan ZR, Pickett JA, Van den Berg J, Wadhams LJ, Woodcock CM (2000) Exploiting chemical ecology and species diversity: stemborer and Striga control for maize and sorghum in Africa. Pest Manage Sci 56:957-962

Khan ZR, Hassanali A, Overholt W, Khamis TM, Hooper AM, Pickett JA, Wadhams LJ, Woodcock CM (2002) Control of witchweed Striga hermonthica by intercropping with Desmodium spp., and the mechanism defined as allelopathic. J Chem Ecol 28:18711885

Khan ZR, Overholt WA, Ng'eny-Mengech A (2003) Integrated pest management case studies from ICIPE. In: Maredia K, Dakouo D, Mota-Sanchez D (eds) Integrated pest management in the global arena. Michigan State University, East Leasing, MI

Khan ZR, James DG, Midega CAO, Pickett JA (2008) Chemical ecology and conservation biological control. Biol Control 45:210-224. doi:10.1016/j.biocontrol.2007.11.009

Kimani SM, Chhabra SC, Lwande W, Khan ZR, Hassanali A, Pickett JA (2000) Airborne volatiles from Melinis minutiflora P. Beauv., a non-host plant of the spotted stem borer. J Essent Oil Res 12:221224

King PD, Mercer CF, Meekings JS (1981) Ecology of black beetle Heteronychus arator. Influence of plant species on larval consumption, utilization and growth. Entomol Exp Appl 29:109-116 
Kirkegaard JA, Sarwar M (1998) Biofumigation potential of brassicas. I. Variation in glucosinolate profiles of diverse field-grown brassicas. Plant Soil 201:71-89

Kirkegaard JA, Sarwar M (1999) Glucosinolate profiles of Australian canola (Brassica napus annua L.) and Indian mustard (Brassica juncea L.) cultivars: implications for biofumigation. Aust J Agric Res 50:315-324

Klopper JW, Rodriguez-Kabana R, Mc Inroy A, Young RW (1992) Rhizosphere bacteria antagonistic to soybean cyst (Heterodera glycines) and root-knot (Meloidogyne incognita) nematodes: identification by fatty acid analysis and frequency of biological control activity. Plant Soil 139:75-84

Klopper JW, Rodriguez-Kabana R, Zehnder GW, Murphy JE, Sikora RA, Fernandez C (1999) Plant root-bacterial interactions in biological control of soilborne diseases and potential extension to systemic and foliar diseases. Australas Plant Pathol 28:21-26

Knudsen IMB, Debosz K, Hockenhull J, Funck JD, Elmholt S (1999) Suppressiveness of organically and conventionally managed soils towards brown foot rot of barley. Appled Soil Ecol 12:61-72

Kokalis-Burelle N, Rodriguez-Kabana R (1994) Effects of pine bark extracts and pine bark powder on fungal pathogens, soil enzyme activity, and microbial populations. Biol Control 4:269-276

Krupinsky JM, Bailey KL, McMullen MP, Gossen BD, Turkington TK (2002) Managing plant disease risk in diversified cropping systems. Agron J 94:198-209

Kvedaras OL, Keeping MG, Goebel R, Byrne M (2005) Effects of silicon on the African stalk borer, Eldana saccharina (Lepidoptera: Pyralidae) in sugarcane. Proc S Afr Sugar Technol Assoc 79:359-362

Kvedaras OL, Keeping MG, Goebel R, Byrne M (2007) Water stress augments silicon-mediated resistance of susceptible sugarcane cultivars to the stalk borer Eldana saccharina (LepidopteraPyralidae). Bull Entomol Res 97:175-183

LaMondia J, Elmer WH, Mervosh TL, Cowles RS (2002) Integrated management of strawberry pests by rotation and intercropping. Crop Prot 21:837-846

Landis DA, Menalled FD (1998) Ecological considerations in the conservation of effective parasitoid communities in agricultural systems. In: Barbosa P (ed) Conservation biological control. Academic, San Diego

Landis DA, Wratten SD, Gurr GM (2000) Habitat management to conserve natural enemies of arthropod pests in agriculture. Annu Rev Entomol 45:175-201

Latheef MA, Irwin RD (1979) The effect of companionate planting on the lepidopteran pests of cabbage. Can Entomol 111:863864

Latheef MA, Ortiz JH (1983) Influence of companion plants on oviposition of imported cabbage worm, Pieris rapae (Lepidoptera: Pieridae), and cabbage looper, Trichoplusia ni (Lepidoptera/ Noctuidae), on collard plants. Can Entomol 115:1529-1531

Latheef MA, Ortiz JH (1984) Influence of companion plant herbs on Phyllotrecta cruciferae (Coleoptera: Chrysomelidae) on collard plants. J Econ Entomol 77:80-82

Lavandero IB, Wratten SD, Didham RK, Gurr G (2006) Increasing floral diversity for selective enhancement of biological control agents: a double-edged sward? Basic Appl Ecol 7:236-243. doi:10.1016/j.baae.2005.09.004

Lelivelt CLC, Hoogendoorn J (1993) The development of juveniles of Heterodera schachtii in roots of resistant and susceptible genotypes of Sinapsis alba, Brassica napus, Raphanus sativus and hybrids. Neth J PI Path 99:13-22

Leroi B, Alzouma I, Huignard J (1990) The influence of intercropping millet (Pennisetum typhoides Burm) with cowpea (Vigna unguiculata Walp) on the egg-laying and development of Bruchidius atrolineatus (Coleoptera: Bruchidae). Agric Ecosyst Environ 31:39-48
Leroux GD, Benoît DL, Banville S (1996) Effect of crop rotations on weed control, Bidens cernua and Erigeron canadensis populations, and carrot yields in organic soils. Crop Prot 15:171-178

Letourneau DK, Drinkwater LE, Shennon C (1996) Effects of soil management on crop nitrogen and insect damage in organic versus conventional tomato fields. Agric Ecosyst Environ 57:174-187

Lewis OT, van Lenteren JC, Phatak SC, Tumlinson JH (1997) A total system approach to sustainable pest management. Proc Natl Acad Sci 94:12243-12248

Liebman M, Altieri MA (1986) Insect, weed and plant disease management in multiple cropping systems. MacMillan, New York

Lima SL (1993) Ecological and evolutionary perspectives on escape from predatory attack - survey of North American birds. Wilson Bull 105:1-47

Long DH, Lee FN, Te Beest DO (2000) Effect of nitrogen fertilization on disease progress of rice blast on susceptible and resistant cultivars. Plant Dis 84:403-409

Lu Z-X, Yu X-P, Heong K-L, Hu C (2007) Effect of nitrogen fertilizer on herbivores and its stimulation to major insect pests in rice. Rice Sci 14:56-66

Maclean RH, Litsinger JA, Moody K, Watson AK (1992) The impact of alley cropping Gliricidia sepium and Cassia spectabilis on upland rice and maize production. Agroforest Syst 20:213-228

Mac Sorley R, Frederick JJ (1995) Responses of some common Cruciferae to root-knot nematodes. J Nematol 23:550-554

Mailloux J, Le Bellec F, Kreiter S, Tixier MS, Dubois P (2010) Influence of ground cover management on diversity and density of phytoseiid mites (Acari: Phytoseiidae) in Guadeloupean citrus orchards. Exp Appl Acarol 52:275-290. doi:10.1007/s10493010-9367-7

Malézieux E, Crozat Y, Dupraz C, Laurans M, Makowski D, OzierLafontaine H, Rapidel B, de Tourdonnet S, Valantin-Morison M (2009) Mixing plant species in cropping systems: concepts, tools and models. A review. Agron Sustain Dev 29:43-62. doi:10.1051/agro:2007057

Matson PA, Parton WJ, Power AG, Swift MJ (1997) Agricultural intensification and ecosystems properties. Science 277:504-509

Matthiessen JN, Kirkegaard JA (2006) Biofumigation and enhanced biodegradation: opportunity and challenge in soilborne pest and disease management. Crit Rev Plant Sci 25:235-265. doi:10.1080/0735268060611543

Mattson WJ Jr (1980) Herbivory in relation to plant nitrogen content. Annu Rev Ecol Syst 11:119-161

McGill WB, Cannon KR, Robertson JA, Cook FD (1986) Dynamics of soil microbial biomass and water-soluble organic $\mathrm{C}$ in Breton $\mathrm{L}$ after 5 years of cropping of two rotations. Can J Soil Sci 66:1-19

Mc Leod RW, Kirkegaard JA, Steel CC (2001) Invasion, development, growth and egg laying by Meloidogyne javanica in Brassicaceae crops. Nematology 3:463-472

McMurtry JA, Croft BA (1997) Life-styles of Phytoseiid mites and their roles in biological control. Annu Rev Entomol 42:291-321

Messiaen CM (1998) Le potager tropical. ACCT, Paris

Messiaen CM, Blancard D, Rouxel E, Lafon R (1991) Les maladies des plantes maraîchères. INRA, Paris

Mian IH, Rodriguez-Kabana R (1982) Organic amendments with high tannin and phenolic contents for control of Meloidogyne arenaria in infested soil. Nematropica 12:221-234

Michel VV, Wang JF, Midmore DJ, Hartman GL (1997) Effects of intercropping and soil amendment with urea and calcium oxide on the incidence of bacterial wilt of tomato and survival of soilborne Pseudomonas solanacearum on Taiwan. Plant Pathol 46:600-610

Miethling R, Wieland G, Backaus H, Tebbe CC (2000) Variation of microbial rhizosphere communities in responses to crop species, 
soil origin, and inoculation with Sinorhizobium meliloti L33. Microb Ecol 40:43-51

Miller JR, Cowles RS (1990) Stimulo-deterrent diversion: a concept and its possible application to onion maggot control. J Chem Ecol 16:197-212

Mills DJ, Coffman CB, Teasdale JR, Everts KL, Anderson JD (2002) Factors associated with foliar disease of staked fresh market tomatoes grown under differing bed strategies. Plant Dis 86:356361

Mitchell CE, Tilman D, Groth JV (2002) Effects of grassland plant species diversity, abundance, and composition on foliar fungal disease. Ecology 83:1713-1726

Mouen Bedimo JA, Njiayouom I, Bieysse D, Ndoumbé NM, Cilas C, Notteghem JL (2008) Effect of shade on Arabica coffee berry disease development: toward an agroforestry system to reduce disease impact. Phytopathology 98:1320-1325. doi:10.1094/ PHYTO-98-12-1320

Muller J (1999) The economic importance of Heterodera schachtii in Europe. Helminthologia 36:205-213

Mundt CC (2002) Use of multiline cultivars and cultivar mixtures for disease management. Annu Rev Phytopathol 40:381-410. doi:10.1146/annurev.phyto.40.011402.113723

Ndung'u DK, Oswald A, Friesen D, Ariga ES, Mburu M (2000) Effect of fodder legumes on stimulation, attachment and emergence of Striga hermonthica on maize. III International Weed Control Congress, Foz do Igassu

Neuman S, Paveley ND, Beed FD, Sylvester-Bradley R (2004) Nitrogen per unit leaf area affects the upper asymptote of Puccinia striiformis f.SP. tritici epidemics in winter wheat. Plant Pathol 53:725-732

Ngugi HK, King SB, Holt J, Julian AM (2001) Simultaneous temporal progress of sorghum anthracnose and leaf blight in crop mixtures with disparate patterns. Phytopathology 91:720-729

Nicholls CI, Altieri MA (2004) Agroecological bases of ecological engineering for pest management. In: Gurr GM, Wratten SD, Altieri MA (eds) Ecological engineering for pest management: advances in habitat manipulation for arthropods. CSIRO publishing, Collingwood, Australia, pp 33-54

Nogueira MA, Oliveira JS, de Ferraz S (1996) Nematicidals hydrocarbons form Mucuna aterrima. Phytochemistry 42:997-998

Ntahimpera N, Ellis MA, Wilson LL, Madden LV (1998) Effects of a cover crop on splash dispersal of Colletotrichum acutatum conidia. Phytopathology 88:536-543

Odunfa VSA (1978) Root exudation in cowpea and sorghum and the effect on spore germination of Eucalyptus blakelyi foliage on the fecundity of Paropsis atomaria (Coleoptera: Chrysomelidae). New Phytol 80:607-612

Ohmart CP, Stewart LG, Thomas JR (1985) Effects of nitrogen concentrations of Eucalyptus blakelyi foliage on the fecundity of Paropsis atomaria (Coleoptera: Chrysomelidae). Oecologia 68:41-44

Oka Y, Ben-Daniel B-H, Cohen Y (2001) Nematicidal activity of powder and extracts of Inula viscosa. Nematology 3:735-742

Östman Ö, Ives AR (2003) Scale-dependent indirect interactions between two prey species through a shared predator. Oikos 102:505-514

Ou SH (1985) Rice diseases. Commonwealth Mycological Institute, Kew

Palm CA, Rowland AP (1997) A minimum dataset for characterization of plant quality for decomposition. In: Cadish G, Giller KE (eds) Driven by nature: plant litter quality and decomposition. CAB International, Wallingford, pp 379-392

Papavizas GC (1963) Microbial antagonists in bean rhizosphere as affected by oat straw and supplement nitrogen. Phytopathology 53:1430-1435

Pasek JE (1988) Influence of wind and windbreaks on local dispersion of insects. Agric Ecosyst Environ 22/23:539-554
Paustian K, Agren GI, Bosatta E (1997) Modelling litter quality effects on decomposition and soil organic matter dynamics. In: Cadish G, Giller KE (eds) Driven by nature: plant litter quality and decomposition. CAB International, Wallingford, pp 313-335

Peachey RE, Moldenke A, William RD, Berry R, Ingham E, Groth E (2002) Effect of cover crops and tillage system on symphylan (Symphlya: Scutigerella immaculata, Newport) and Pergamasus quisquiliarum Canestrini (Acari: Mesostigmata) populations, and other soil organisms in agricultural soils. Appled Soil Ecol 21:59-70

Pepperman AB, Blanchard EJ (1985) Improvements in the synthesis of strigol and its analogs. ACS Symp Ser Am Chem Soc USA 268:415-425

Perfecto I, Vandermeer J (1996) Microclimatic changes and the indirect loss of ant diversity in a tropical system. Oecologia 108:577-582

Perfecto I, Vandermeer J (2008) Spatial pattern and ecological process in the coffee agroforestry system. Ecology 89:915-920

Perfecto I, Rice R, Greenberg R, Van der Voort M (1996) Shade coffee: a disappearing refuge for biodiversity. Bioscience 46:598-608

Perkins TE, Matlack GR (2002) Human-generated pattern in commercial forests of southern Mississippi and consequences for the spread of pests and pathogens. For Ecol Manage 157:143-154

Peterson PD, Leonard KJ, Roelfs AP, Sutton TB (2005) Effects of barberry eradication on changes of Puccinia graminis in Minnesota. Plant Dis 89:935-940

Pimentel D, Warneke A (1989) Ecological effects of manure, sewage sludge and other organic wastes on arthropod populations. Agric Zool Rev 3:1-30

Power AG, Flecker AS (2008) The role of vector diversity on disease dynamics. In: Ostfeld RS, Keesing F, Eviner V (eds) Infectious disease ecology: effects of ecosystems on disease and of disease on ecosystems. Princeton University Press, Princeton, pp 30-48

Prasifka JR, Schmidt NP, Kohler KA, O’Neal ME, Hellmich RL, Singer JW (2006) Effects of living mulches on predator abundance and sentinel prey in a corn-soybean-forage rotation. Environ Entomol 35:1423-1431

Primavesi AM, Primavesi A, Veiga C (1972) Influence of nutritional balances of paddy rice resistance to blast. Agrochimica 16:459-472

Pyke B, Rice R, Sabine B, Zalucki MP (1987) The push-pull strategy - behavioural control of Heliothis. Aust. Cotton Grow. MayJuly, 7-9

Rasmussen PE, Collins HP, Smiley RW (1989) Long-term management effects on soil productivity and crop yield in semi-arid regions of eastern Oregon. USDA-ARS, Pendleton

Rataul HS, Gill CK, Brar S (1989) Use of barrier crop and some cultural measures in the management of yellow mosaic virus on soybean. J Res Punjab Agr Univ 26:227-230

Ratnadass A, Randriamanantsoa R, Rabearisoa MY, Rajaonera TE, Rafamatanantsoa E, Isautier C (2006a) Dynastid white grubs as rainfed rice pests or agrosystem engineers in Madagascar. 2nd International Rice Research Congress, 9-13 October 2006, New Delhi, India. CIRAD, Montpellier, $1 \mathrm{p}$

Ratnadass A, Michellon R, Randriamanantsoa R, Séguy L (2006b) Effects of soil and plant management on crop pests and diseases. In: Uphoff NT, Ball AS, Fernandes ECM, Herren HR, Husson O, Laing MV, Palm C, Pretty J, Sanchez P, Sanginga N, Thies J (eds) Biological approaches to sustainable soil systems. CRC, Boca Raton, pp 589-602.

Ratnadass A, Avelino J, Fernandes P, Habib R, Letourmy P, Sarah JL (2010) Designing ecologically intensive cropping systems for regulating pests and diseases via plant species diversificationbased suppressive processes in the tropics. In: Proceedings of Agro2010 the XIth ESA Congress, Aug 29-Sep 3, Montpellier, France, pp 523-524 
Reynolds AM, Reynolds DR (2009) Aphid aerial density profiles are consistent with turbulent advection amplifying flight behaviours: abandoning the epithet « passive ». Proc R Soc B 276:137-143. doi:10.1098/rspb.2008.0880

Ricci B, Franck P, Toubon JF, Bouvier JC, Sauphanor B, Lavigne C (2009) The influence of landscape on insect pest dynamics: a case study in southeastern France. Landscape Ecol 24:337-349. doi:10.1007/s10980-008-9308-6

Ridsill Smith TJ (1975) Selection of living grass roots in the soil by larvae of Sericesthis nigrolineata (Coleoptera: Scarabaeidae). Entomol Exp Appl 18:75-86

Ristaino JB, Parra G, Campbell CL (1997) Suppression of Phytophthora blight in bell pepper by a no-till wheat cover crop. Phytopathology 87:242-249

Robinson KA, Jonsson M, Wratten SD, Wade MR, Buckley HL (2008) Implications of floral resources for predation by an omnivorous lacewing. Basic Appl Ecol 9:172-181. doi:10.1016/j. baae.2007.01.002

Rodrigues FA, Vale FXR, Korndorfer GH, Prabhu AS, Datnoff AMA, Oliveira LE, Zambolim L (2003) Influence of silicon on sheath blight of rice in Brazil. Crop Prot 22:23-29

Rodriguez-Kabana R, Kokalis-Burelle N (1997) Chemical and biological control. In: Hillocks RJ, Waller JM (eds) Soilborne diseases of tropical crops. CAB International, Wallingford, $\mathrm{pp}$ 397-418

Room PM, Smith ESC (1975) Relative abundance and distribution of insect pests, ants and other components of the cocoa ecosystem in Papua New Guinea. J Appl Ecol 12:31-46

Root RB (1973) Organization of a plant-arthropod association in simple and diverse habitats: the fauna of collards (Brassica oleracea). Ecol Monogr 43:94-125

Rypstra AL, Carter PE, Balfour RA, Marshall SD (1999) Architectural features of agricultural habitats and their impact on the spider inhabitants. J Arachnology 27:371-377

Sall SN, Masse D, Bernhard-Reversat F, Guisses A, Chotte JL (2003) Microbial activities during the early stage of laboratory decomposition of tropical leaf litters: the effect of interactions between litter quality and exogenous inorganic nitrogen. Biol Fertil Soils 39:103-111. doi:10.1007/s00374-003-0679-1

Sanchez de Viala S, Brodie BB, Roriguez E, Gibson DM (1998) The potential of thiarubrine $\mathrm{C}$ as a nematicidal agent against plantparasitic nematodes. J Nematol 30:192-200

Sarniguet A, Lucas P, Lucas M (1992a) Relationships between takeall, soil conductiveness to the disease, populations of fluorescent pseudomonas and nitrogen fertilizers. Plant Soil 145:17-27

Sarniguet A, Lucas P, Lucas M, Samson R (1992b) Soil conductiveness to take-all of wheat: influence of the nitrogen fertilizers on the structure of populations of fluorescent pseudomonas. Plant Soil 145:29-36

Sarwar M, Kirkegaard JA (1998) Biofugimation potential of brassicas. II. Effect of environment and ontogeny on glucosinolate production and implications for screening. Plant Soil 201:91-101

Schellhorn NA, Sork VL (1997) The impact of weed diversity on insect population dynamics and crop yield in collards, Brassica oleracea (Brassicaceae). Oecologia 111:233-240

Schlathoelter NA (2004) Biofumigation with nematode resistant crops. Agroindustria 3:407

Schloter M, Munch JC, Tittarelli F (2006) Managing soil quality. In: Bloem J, Hopkins DW, Benedetti A (eds) Microbiological methods for assessing soil quality. $\mathrm{CAB}$ International, Wallingford, pp 50-62

Schmidt MH, Thiès C, Tscharntke T (2004) Landscape context of arthropod biological control. In: Gurr GM, Wratten SD, Altieri MA (eds) Ecological engineering for pest management: advances in habitat manipulation for arthropods. CSIRO publishing, Collingwood, Australia, pp 55-63
Schmidt MH, Roschewitz I, Thiès C, Tscharntke T (2005) Differential effects of landscape and management on diversity of grounddwelling farmland spiders. J Appl Ecol 42:281-287. doi:10.1111/ j.1365-2664.2005.01014.x

Scholte K (2000a) Screening of nontuber bearing Solanaceae for resistance and induction of juvenile hatch of potato cyst nematodes and their potential for trap cropping. Ann Appl Biol 136:239-246

Scholte K (2000b) Growth and development of plants with potential for use as trap crops for potato cyst nematodes and their effects on the number of juveniles in cysts. Ann Appl Biol 137:31-42

Scholte K, Vos J (2000) Effects of potential trap crops and planting date on soil infestation with potato cyst nematodes and root-knot nematodes. Ann Appl Biol 137:153-164

Schoonhoven LM, van Loon JJA, Dicke M (2006) Insect-plant biology. Oxford University Press, Oxford

Schroth G, Krauss U, Gasparotto L, Duarte Aguilar JA, Vohland K (2000) Pests and diseases in agroforestry systems of the humid tropics. Agroforest Syst 50:199-241

Schulthess F, Setamou F (1999) Canavalia ensiformis et Mucuna pruriens plantes-hôtes intermédiaires du ravageur du maïs Mussidia nigrivenella Ragonot (Lepidoptera: Pyralidae). CIEPCA Newslett 4:2

Scopel E, Da Silva FAM, Corbeels M, Affholder F, Maraux F (2004) Modelling crop residue mulching effects on water use and production of maize under semi-arid and humid tropical conditions. Agronomie 24:383-395. doi:10.1051/agro:2004029

Séguy L, Notteghem JL, Bouzinac S (1981) Etude des interactions sol-variétés de riz-pyriculariose, Comptes-rendus du symposium sur la résistance du riz à la pyriculariose. IRAT-GERDAT, Montpellier, pp 138-151

Séguy L, Bouzinac S, Pacheco A (1989) Les principaux facteurs qui conditionnent la productivité du riz pluvial et sa sensibilité à la pyriculariose sur sols rouges ferrallitiques d'altitude. IRATCIRAD/EMBRAPA, Montpellier, France

Sester M, Raboin LM, Ramanantsoanirina A, Tharreau D (2008) Toward an integrated strategy to limit blast disease in upland rice. ENDURE International Conference 2008: diversifying crop protection, 12-15 October 2008, La Grande-Motte, France. $\mathrm{O} .36,4 \mathrm{pp}$

Sharma SR, Verma A (1984) Effect of cultural practices on virus infection in cowpea. Z Acker Planzenbau 153:23-31

Shelton AM, Badenes-Perez FR (2006) Concepts and applications of trap cropping in pest management. Ann Rev Entomol 51:285308. doi:10.1146/annurev.ento.51.110104.150959

Shelton AM, Nault BA (2004) Dead-end trap cropping: a technique to improve management of the diamondback moth, Plutella xylostella (Lepidoptera: Plutellidae). Crop Prot 23:497-503. doi:10.1016/j.cropro.2003.10.005

Simmons AT, Gurr GM (2005) Trichomes of Lycopersicon species and their hybrids: effects on pests and natural enemies. Agric For Entomol 7:265-76. doi:10.1111/j.1469-9555.2005.00271.x

Singh Rathore MP (1995) Insect pests in agroforestry. ICRAF working paper. $70,73 \mathrm{pp}$

Smith JG (1976) Influence of crop background on aphids and other phytophageous insects on Brussels sprouts. Ann Appl Biol 83:1-13

Smith HA, McSorley R (2000) Potential of field corn as a barrier crop and eggplant as a trap crop for management of Bemisia argentifolii (Homoptera: Aleyrodidae) on common bean in North Florida. Florida Entomol 83:145-158

Smith HJ, Gray FA, Koch DW (2004) Reproduction of Heterodera schachtii Schmidt on resistant mustard, radish, and sugar beet cultivars. J Nematol 36:123-130

Smithson JB, Lenné JM (1996) Varietal mixtures: a viable strategy for sustainable productivity in subsistence agriculture. Ann Appl Biol 128:127-158 
Spiegel Y, Cohn E, Galper S, Sharon E, Chet I (1991) Evaluation of a newly isolated bacterium, Pseudomonas chitinolytica sp. nov., for controlling the root-knot nematode Meloidogyne javanica. Biocontrol Sci Technol 1:115-125

Staver C, Guharay F, Monterroso D, Muschler RG (2001) Designing pest-suppressive multistrata perennial crop systems: shade-grown coffee in Central America. Agroforest Syst 53:151-170

Stirling GR, Stirling AM (2003) The potential of Brassica green manure crops for controlling root-knot nematode (Meloidogyne javanica) on horticultural crops in a subtropical environment. Aust J Exp Agric 43:623-630. doi:10.1071/EA02175

Styrsky J, Kaplan I, Eubanks MP (2006) Plant trichomes indirectly enhance tritrophic interactions involving a generalist predator, the red imported fire ant. Biol Control 36:375-384. doi:10.1016/j. biocontrol.2005.10.003

Sutherland ORW, Greenfield WJ (1976) A new toxin for grass grub and black beetle in resistant Lotus major. Proceedings of the Twenty-ninth New Zealand Weed and Pest Control Conference. pp $158-160$

Teetes GL, Anderson RM, Peterson GC (1994) Exploitation of sorghum nonpreference resistance to sorghum midge (Diptera: Cecidomyiidae) using mixed plantings of resistant and susceptible sorghum hybrids. J Econ Entomol 87:826-831

Terblanche J (2002) The use of a biologically active rotation crop for the suppression of Ralstonia solanacearum in soils used for tobacco production. Bact Wilt News1 17:8-9

Theunissen J, Schelling G (1996) Pest and disease management by intercropping: suppression of thrips and rust in leek. Int J Pest Manage 42:227-234

Thompson JN (1988) Evolutionary ecology of the relationship between oviposition preference and performance of offspring in phytophageous insects. Entomol Exp Appl 47:3-14

Thompson JN, Pellmyr O (1991) Evolution of oviposition behaviour and host preference in Lepidoptera. Ann Rev Entomol 36:6589

Thorup-Kristensen K, Magid J, Jensen LS (2003) Catch crops and green manures as biological tools in nitrogen management in temperate zones. Adv Agron 79:227-302. doi:10.1016/S00652113(02)79005-6

Tian H, Riggs RD, Crippen DL (2000) Control of soybean cyst nematode by chitinolytic bacteria with chitin substrate. J Nematol 32:370-376

Tillman PG, Mullinix BG Jr (2004) Grain sorghum as a trap crop for corn earworm (Lepidoptera: Noctuidae) in cotton. Environ Entomol 33:1371-1380

Tilman D, Cassman KG, Matson PA, Naylor R, Polasky S (2002) Agricultural sustainability and intensive production practices. Nature 418:671-677. doi:10.1038/nature01014

Timmermans BGH, Vos J, Stomph TJ, Van Nieuwburg J, Van der Putten PEL (2005) Growth duration and root length density of Solanum sisymbriifolium (Lam.) as determinants of hatching of Globodera pallida (Stone). Ann Appl Biol 148:213-222

Tiyagi SA, Suhail A, Mehar B, Siddiqui MA (1986) Feasibility of growing Zinnia as a mix-crop along with tomato for control of root-knot and reniform nematodes. Int Nematol Netw Newslett 3:6-7

Tscharntke T, Brandl R (2004) Plant-insect interactions in fragmented landscapes. Annu Rev Entomol 49:405-430. doi:10.1146/ annurev.ento.49.061802.123339

Tscharntke T, Bommarco R, Clough Y, Crist TO, Kleijn D, Rand TA, Tylianakis JM, van Nouhuys S, Vidal S (2007) Conservation biological control and enemy diversity on a landscape scale. Biol Control 43:294-309. doi:10.1016/j.biocontrol.2007.08.006

Turlings TCJ, Tumlinson JH, Lewis WJ (1990) Exploitation of herbivore-induced plant odors by host-seeking parasitic wasps. Science 250:1251-1253
Tylianakis JM, Didham RK, Wratten SD (2004) Improved fitness of aphid parasitoids receiving resource subsidies. Ecology 85:658666

Uvah III, Coaker TH (1984) Effect of mixed cropping on some insect pests of carrots and onions. Entomol Exp Appl 36:159-167

Vail SL, Dailey OD, Blanchard EJ, Pepperman AB, Riopel JL (1990) Terpenoid precursors of strigol as seed germination of broomrape (Orobanche ramosa) and witchweed (Striga asiatica). J Plant Growth Regul 9:77-83

Van Bruggen AHC, Grunwald NJ (1996) Test for risk assesment of root infection by plant pathogens. In: Doran JW, Jones AJ (eds) Methods for assessing soil quality. SSSA, Madison, pp 293-310

Van den Berg J (2006) Vetiver grass (Vetiveria zizanoides (L.) Nash) as trap plant for Chilo partellus (Swinhoe) (Lepidoptera: Pyralidae) and Busseola fusca (Fuller) (Lepidoptera: Noctuidae). Ann Soc Entomol Fr 42:449-454

Vandermeer J, Perfecto I, Liere H (2009) Evidence for hyperparasitism of coffee rust (Hemileia vastatrix) by the entomogenous fungus, Lecanicillium lecanii, through a complex ecological web. Plant Pathol 58:636-641. doi:10.1111/j.1365-3059.2009.02067.x

Van Emden HF (1965) The role of uncultivated land in the biology of crop pests and beneficial insects. Sci Hortic 17:121-136

Van Mele P, Cuc NTT (2007) Ants as friends: improving your tree crops with weaver ants, 2nd edn. Africa Rice Center (WARDA), Cotonou, Benin, 72 pp.

Van Nouhuys S, Hanski I (2002) Colonization rates and distances of a host butterfly and two specific parasitoids in a fragmented landscape. J Anim Ecol 71:639-650

Vicente NE, Acosta N (1987) Efecto de Mucuna deeringiana en una poblacion de Meloidogyne incognita. Nematropica 17:99-102

Vilich-Meller V (1992) Pseudocercosporella herpotrichoides, Fusarium spp. and Rhizoctonia cerealis stem rot in pure stands and interspecific mixtures of cereals. Crop Prot 11:45-50

Virk JS, Brar KS, Sohi AS (2004) Role of trap crops in increasing parasitation efficiency of Trichogramma chilonis Ishii in cotton. J Biol Control 18:61-64

Voleti SR, Padmakumari AP, Raju VS, Babu SM, Subramania R (2008) Effect of silicon solubilizers on silica transportation, induced pest and disease resistance in rice (Oryza sativa L.). Crop Prot 27:1398-1402. doi:10.1016/j.cropro.2008.05.009

Vollhardt IMG, Tscharntke T, Wäckers FL, Bianchi FJJA, Thiès C (2008) Diversity of cereal aphid parasitoids in simple and complex landscapes. Agric Ecosyst Environ 126:289-292. doi:10.1016/j.agee.2008.01.024

Wäckers FL, van Rijn PCJ, Heimpel GE (2008) Honeydew as a food source for natural enemies: making the best of a bad meal? Biol Control 45:176-184. doi:10.1016/j.biocontrol.2008.01.007

Walters DR, Bingham IJ (2007) Influence of nutrition on disease development caused by fungal pathogens: implications for plant disease control. Ann Appl Biol 151:307-324. doi:10.1111/ j.1744-7348.2007.00176.x

Wang K-H, McSorley R, Gallaher RN (2003) Effect of Crotalaria juncea amendment on nematode communities in soil with different agricultural histories. J Nematol 35:294-301

Wang KH, McSorley R, Gallaher RN (2004) Effect of Crotalaria juncea amendment on squash infected with Meloidogyne incognita. J Nematol 36:290-296

Wang KH, McSorley R, Marshall AJ, Gallaher RN (2006) Influence of organic Crotalaria juncea hay and ammonium nitrate fertilizers on soil nematode communities. Appl Soil Ecol 31:186-198. doi:10.1016/j.apsoil.2005.06.006

Wardle DA, Yeates GW, Watson RN, Nicholson KS (1995) The detritus foodweb and the diversity of soil fauna as indicators of disturbance regimes in agroecosystems. Plant Soil 170:35-43

Way MJ, Khoo KC (1991) Colony dispersion and nesting habits of ants, Dolichoderus thoracicus and Oecophylla smaragdina (Hymenop- 
tera: Formicidae), in relation to their success as biological control agents on cocoa. Bull Entomol Res 81:341-350

Weinhold AR, Oswald JW, Bowman T, Bishop J, Wright D (1964) Influence of green manures and crop rotation on common scab of potato. Am Potato J 41:265-273

Weller DM, Raaijmakers JM, Gardener BB, Thomashow LS (2002) Microbial populations responsible for specific soil suppressiveness to plant pathogens. Ann Rev Phytopathol 40:309-348. doi:10.1146/ annurev.phyto.40.030402.110010

Welsh JP, Philipps L, Bulson HAJ, Wolfe M (1999) Weed control strategies for organic cereal crops. 1999 Brighton Crop Protection Conference-Weeds, Brighton, pp 945-950

Weston LA (1996) Utilization of allelopathy for weed management in agroecosystems. Agron J 88:860-866

Widmer TL, Abawi GS (2000) Mechanisms of suppression of Meloidogyne hapla and its damage by a green manure of sudangrass. Plant Dis 84:562-568

Widmer TL, Abawi GS (2002) Relationship between levels of cyanide in sudangrass hybrids incorporated into soil and suppression of Meloidogyne hapla. J Nematol 34:16-22

Wolfe M (2000) Crop strength through diversity. Nature 406:681-682
Wood D, Lenné J (2001) Nature's fields: a neglected model for increasing food production. Outlook Agric 30:161-170

Youm O, Sithanantham S, Vaissayre M, Nibouche S, Martin T, Ochou GO, Monmanyi G (2005) Bio-ecology and management of Helicoverpa for sustainable crop production in Africa. In: Sharma HC (ed) Heliothis/Helicoverpa management, emerging trends and strategies for future research. Oxford, New Delhi, pp 63-90

Yu JR (1999) Allelopathic suppression of Pseudomonas solonacearum infection of tomato (Lycopersicon esculentum) in tomato-Chinese chive (Allium tuberosum) intercropping system. J Am Chem Soc 69:273

Zadoks JC (1999) Reflections on space, time, and diversity. Annu Rev Phytopathol 37:1-17

Zhou XG, Everts KL (2007) Effects of host resistance and inoculum density on the suppression of Fusarium wilt of watermelon induced by hairy vetch. Plant Dis 91:92-96. doi:10.1094/PD-91-0092

Zhu Y, Chen H, Fan JH, Wang Y, Li Y, Fan JX, Chen J, Fan JX, Yang $\mathrm{S}$, Hu L, Leung H, Mew TW, Teng PS, Wang Z, Mundt CC (2000) Genetic diversity and disease control in rice. Nature 406:718-722 